\title{
Türkiye’de Sosyal Politikanın Dünü, Bugünü: Hayırseverliğin Kurumsallaşması mı? Gelişim mi?
}

\author{
Yener ŞISSMAN*
}

ÖZ

Cumhuriyet Türkiye'si ekonomik, sosyal, kültürel alanlarda Osmanlı'nın mirası üzerine kurulmuş, sözü edilen alanlarda kırılmadan ziyade yumuşak bir geçiş gerçekleşmiştir. Bu nedenle, Türkiye'deki sosyal politika uygulamalarının bugününü kavrayabilmek için geçmişin bilinmesi, konunun Osmanlı'daki yapının değişimi ve dönüşümü çerçevesinde irdelenmesi gereklidir. Bu çalışma, Türkiye'de sosyal politikanın tarihsel gelişimini ortaya koymak ve bugüne ilişkin yansımaları olan geçmiş dönem uygulamalarının mevcut biçimini analiz etmek amacındadır. Çalışmanın sonucunda Türkiye'deki sosyal politika uygulamalarının kimi farklılıkları içinde barındırsa da Osmanlı'dan günümüze kadar; ekonomik ve sosyal yap1 ile uyumlu bir biçimde geliştiği, gönüllülük ve hayırseverlik düşüncesine dayalı temel yapısını koruduğu, "sosyal devlet" anlayışının ise zaman içinde ve aşamalı bir gelişme gösterdiği vurgulanmıştır.

Anahtar Kelimeler: Sosyal Politika, Sosyal Politika Tarihi, Sosyal Devlet, Hayırseverlik

JEL Sinıflandırması: J80, J83, J88

\section{Past and Current States of Social Policy in Turkey: Is it Philanthropy Institutionalized? Is it Progress?}

\begin{abstract}
Republic of Turkey was founded on the heritage of the Ottomans in economic, social and cultural areas, and a soft, not sharp, transition, occurred in the these areas. Therefore, in order to understand the current state of social policy practices in Turkey, it is necessary to know about the past and to examine the subject within the framework of the change and transformation in the Ottoman structure. The purpose of this study is to reveal the historical development of social policy in Turkey and to examine the current form of the practices that have reflections into the present time. In conclusion it has emphasized that social policy practices in Turkey include certain differences, yet up until now, these practices have developed in accordance with the economic and social structure and protected the notion of voluntariness and benevolence and that the understanding of "social state" has developed gradually in time.
\end{abstract}

Keywords: Social Policy, History of Social Policy, Social State, Charity

JEL Classification: J80, J83, J88

Yrd. Doç. Dr., Anadolu Üniversitesi, İİBF, Çalışma Ekonomisi ve Endüstri İlişkileri Bölümü, ysisman@anadolu.edu.tr 


\section{GİRIŞ̧}

Türkiye' de sosyal politikanın tarihsel gelişimini sağlıklı bir biçimde değerlendirebilmek için, bu politikaların içerisinde doğup geliştiği ortam ve koşullar çerçevesinde incelenmesi gerekir. Bu nedenle tarihsel süreçte sosyal, siyasal ve ekonomik gelişmeler irdelenirken aynı zamanda arka planda yer alan aktörler de ele alınmalıdır. Zira Türkiye'de sosyal politika, hemen her zaman; hâkim ekonomik işleyiş, siyasal düşünce ve sosyal yapı ile uyum içinde seyretmiştir.

Ayrıca Osmanlı İmparatorluğu ile Türkiye Cumhuriyeti arasında, ekonomik ve sosyal alanda radikal bir kopuştan ziyade yumuşak bir geçiş söz konusu olduğu için Türkiye'deki sosyal politikaların tarihsel gelişiminin anlaşılabilmesi açısından Osmanlıdaki durumun da bilinmesi zorunludur. Elbette sosyal nitelikte modern kamusal politikaların esas itibariyle Cumhuriyet Dönemi ile birlikte izlenmeye başlandığını, bu anlamda Cumhuriyetin önemli bir dönüşümün başlangıcı ve Türkiye' de sosyal politikaların tarihsel gelişimi açısından bir dönüm noktası olduğunu kabul etmek uygun olacaktır. Bu düşünce ile ülkemizde sosyal politikanın tarihsel gelişimi Cumhuriyet Öncesi ve Cumhuriyet Dönemi olarak iki ana bölüm içinde ele alınacaktır. Bu dönemlerin kendi içinde belirgin farklılıkların var olduğu alt bölümlere ayrılması ise değerlendirme yapabilmeyi kolaylaştırmak amacına yöneliktir.

Diğer yandan Avrupa'daki modern sosyal politikaların gelişimine bakıldığında, tarihsel süreçte ilk olarak işçilerin odak noktasında yer aldığı, işçi sınıfının olumsuz çalışma koşulları ve kötü niyetli olabileceği varsayılan fabrika sahibine karşı iş yasaları ile korunmaya çalışıldığ görülür. $\mathrm{Bu}$ nedenle çalışmamızda önceliğimiz, iş ilişkileri ve çalışma yaşamı olacak, yoksulluğun önlenmesi, engellilerin toplumla bütünleştirilmesi, çocukların korunması, sosyal güvenlik gibi konulara tarihsel süreçte yeri geldikçe ve imkân oldukça değinilmeye çalışılacaktır.

\section{CUMHURIYYT ÖNCESİ DÖNEM VE SOSYAL POLITIKKALAR}

Osmanlı İmparatorluğunda bütün güç ve yetkinin Sultan'da toplandığ teokratik bir devlet anlayışı egemendir ve demokratikleşme açısından çeşitli girişimlerin varlığına karşın, İmparatorluk bütün yaşamı boyunca mutlak bir devlet görüntüsünden uzaklaşmamıştır. Bu yap1 içerisinde modern anlamda bir sosyal politika da doğup gelişememiştir (Koray, 2000:98-164). Öte yandan, İmparatorluğun içinde bulunduğu koşullar nedeniyle sanayinin Cumhuriyet Dönemi'ne dek önemli bir gelişme gösteremediğini, buna bağlı olarak ücretlilik ilişkisinin yaygınlaşmadığını ve önemli bir işçi hareketinin de oluşmadığını söyleyebiliriz (Koray, 2000:98; Boratav, 2003:33).

Cumhuriyet'e dek geçen dönem belirgin farklıliklarından hareketle, Tanzimat'a dek Geçen Dönem ve Tanzimat ve Meşrutiyet Dönemi olarak iki ayrı başlık altında dönemselleştirilebilir.

\subsection{Tanzimat'a dek Geçen Dönem}

Osmanlı İmparatorluğunda, kalabalık aileler, sıkı akrabalık, komşuluk ilişkileri ile dini düşüncelerle biçimlenen geleneksel destekler çerçevesinde, özellikle toplumun korunması gereken güçsüz kesimlerine yönelik (yoksullar, hastalar, dullar, yetimler vb.) geniş bir sosyal koruma hizmetinin varlığından bahsedilebilir (Altan, 2008:65). Ancak her toplumda rastlanabilecek ve medeniyetin başlangıcından beri var olduğu iddia edilen bu tür sosyal koruma hizmetleri, insani yardım kapsamında değerlendirilmelidir. Hatta bu hizmetlerin varlığının, kurumsal sosyal politika yönündeki talepleri geciktirdiği bile söylenilebilir (Güvercin, 2004:91).

Devamlılı̆g olmayan, acıma, merhamet gibi insani hislerle veya dini duygularla yapılan bu yardımlar, bireyleri başka bireylerin insafına bırakmakta, kaynakların dağıtımında dağınıklık 
ve dengesizlik söz konusu olabilmektedir. Nasıl, ne zaman ve kimlere yapılacağına ilişkin kurumsal bir çerçevenin de bulunmaması nedeniyle bu yardımlar modern anlamda bir sosyal politika tedbiri olarak değerlendirilemez (Bedir vd., 2012a:10). Zira bir uygulamanın modern anlamda sosyal politika olarak değerlendirilmesi için; hak temelli olması, kurumsal, düzenli ve standart olmas1 gerekmektedir.

Yine de bu dönemde, büyük ölçüde İslam dininden kaynaklanan zekât, fitre, sadaka, kurban kesme vb. şeklinde ortaya çıkan ve dar gelirliler ile muhtaçlara yönelik yapılan yardımların, gelirin belirli ölçülerde yeniden ve göreli olarak adil dağılımını amaçladığı ve büyük ölçüde başarı sağladığı ifade edilmelidir (Makal, 1997:212-213; Dilik, 1988:57). Ayrıca İmparatorluk'ta yaygın bir biçimde bulunan vakıf ve lonca gibi örgütlü yapıların, sosyal yardımlar konusunda İslam dininden kaynaklanan yardımlara kıyasla daha etkin olduğu da söylenmelidir.

Varlıklı kişilerin, özellikle taşınmaz mallarının gelirlerini, dini ve sosyal amaçlı hizmetlerin görülmesi için kurmuş oldukları kurumların finansmanına tahsis etmeleri ve bu amaçla malların mülkiyetini sözü edilen kurumlara devretmeleri anlamına gelen vakıf müessesesi, tüm dünyadaki en başarılı örneklerini Osmanlı'da vermiştir. Siyasi nitelikte olan ve otoriteye ihtiyaç gösteren, iç ve dış güvenlik gibi hizmetler devlet eliyle yürütülürken, eğitim, sağlık, sosyal güvenlik gibi birçok alanda Osmanlı toplumunun ihtiyaçlarına cevap veren temel toplumsal kurum vakıf müessesesidir. Başta padişahlar, devlet yetkilileri ve zenginler tarafından kurulan bu vakıflara devlet de vergi muafiyetleri ile dolaylı olarak destek vermiştir (Bedir vd., 2012a:45; Bedir vd., 2012b:63; Dilik, 1988:63).

İş ilişkilerinin düzenlenmesinde ise, Avrupa ülkelerine olduğu gibi, Osmanlı'da da esnaf örgütleri büyük bir rol oynamıştır. Esnaf örgütleri başlangıçta Doğu ve İslam etkisi altında kalmış, fütüvvet geleneğinden yoğun ölçüde etkilenmiş ve 13. Yüzyıldan itibaren Anadolu'da dini ve mesleki karakterli bir müessese olarak "Ahilik" adı ile yayılmıştır (Özcan, 2006:41).

Soy temizliği, mertlik, eli açıklık, cömertlik, yiğitlik anlamına gelen "fütüvvet" ve buna dayalı anlayış, örgütlü bir tavır olarak İslam'ın ilk dönemlerinde ortaya çıkmış, tasavvufi yaşayışta bir mertebe ve güzel davranış şeklinde algılanarak kitleleri cezbetmiş, muhtelif adlarla İslam dünyasının hemen her yöresinde ve her asırda varlığını devam ettirmiştir. Fütüvvet kelimesi, ahlâkî ve insanî üstün meziyetlerden olan kahramanlık, hak ve hukuka riayet etmek, fazilet icaplarını yerine getirmek, güzel huylu ve feragat sahibi olmak, malıyla ve gücüyle başkalarına yardıma koşmak, bağışlayıcı olmak ve Allah yolunda nefsini hakir tutmak gibi anlamlar taşır. Bu yüksek meziyetlere sahip olan "fetâ" ideal insan tipidir. Ahi kelimesi ise genel kabule göre "kardeşim" anlamındadır. Ancak Ahilik müessesesi tasavvufi anlamda cömertliğe, el açıklığına, mertliğe dayanan ve fertlerin birbirini kardeş görmelerinin ifadesidir. Fütüvvet anlayışı içinde bir sanat sahibi olanlara "ahi" denilmektedir. Dolayısıyla ahilik fütüvvetle bağlant1lıdır (Dilik, 1988: 58; Karasoy, 2004: 2-18; Yazıc1, ?:67-71; Yazıc1, 1996:74-77).

Osmanlı Beyliği'nin kuruluşu sırasında fütuhatı başarmak için askeri faaliyetler içinde yer alan, orduya yardım eden ve lojistik destek sağlayan Ahiler, halk arasında dini fikirlerin yayılmasında da önemli roller üstlenmişler. Âhi teşkilatı, Âhi tarikatına bağlıdır ve bu anlamda teşkilata dini bir disiplin, dini ve milli bir hiyerarşi hâkimdir. Bu yapı içinde ustaların, yanlarında çalışan yamak, çırak ve kalfaların her türlü sorunları ile meşgul olduğu, onların bir yandan iyi birer usta olmalarını sağlamaya çalışırken, diğer yandan tüm özel yaşantılarını tam bir kontrol altında bulundurduğu görülür (Sevinç, 1978:62).

Bir esnaf örgütü olarak bu yapının konumuz açısından en önemli fonksiyonu ise, ekonomik faaliyetlerin, mümkün olduğu kadar az ihtilaf oluşturacak şekilde, sosyal dayanışma ve ahenk içerisinde gerçekleşmesini sağlamaktı (ITTO, 2006:87). Bu nedenle Âhiler, rekabete değil, işbirliği ve karşılıklı kontrol ilkelerine bağlı olarak çalışmışlar, başta mensupları olmak 
üzere, insanlar arasında dayanışmayı ve yardımlaşmayı oluşturmayı amaçlamışlardır (ITO, 2006:53; Bedir vd., 2012a:45; Bedir vd.,2012b:63).

Ancak, Âhi teşkilatının esnaf ve sanatkârlar üzerindeki etkilerinin 15. Yüzyılın ortalarından sonra azaldığı belirtilmelidir. Esnaf, kendi sorunlarını serbestçe, katı kural ve koşullara bağlı olmaksızın görüşebilmek ve herkesin uyabileceği kararlar alabilmek için, önceleri toplandığı dergâh ve zaviyeleri yavaş yavaş terk etmiş, Müslüman ya da Müslüman olmayan ayrımı yapılmaksızın bir araya gelerek "lonca" adıyla örgütlenmeye başlamıştır (Karasoy, 2004:16). Bu anlamda loncaların farkı, âhilikteki gibi bir inanç etrafında bir araya gelmekten ziyade mensuplarının menfaatlerini korumak üzere oluşturulmuş müesseseler olmasıdır (Büyükboyac1, 1986:164).

Devletin uyguladığı merkeziyetçi politikaya ayak uydurabilen, devletin denetim ve gözetimine her an açık olan lonca teşkilatı, hızla güçlenerek esnaf ve sanatkârlara egemen olmuştur. Böylece, Batı ülkeleri ve Batı kültürü ile çoğalan ilişkilerin de etkisiyle, Avrupa'daki örneklerine benzeyen esnaf örgütlenmeleri Osmanlı İmparatorluğu'na da yerleşmiştir (Altan, 2008:66; Dilik, 1988:61).

Her loncanın bir teavün sandığı (orta sandığı) bulunmaktadır ve bazı loncaların sandıkları gerçek bir banka gibi zengindir (Büyükboyac1, 1986:168). Bu sandıktan yapılan harcamalar ise büyük bir çeşitlilik göstermektedir. Lonca üyelerinden herhangi birisinin, engellilik, yaşlılık, hastalık ve ölüm gibi sosyal riskler ile karşılaşması durumunda, gereksinim duyulursa bu sandıktan ödemede bulunulmaktaydı (Makal, 1997:213-214; Makal, 2016:93). Bu anlamda loncaların bir sosyal güvenlik fonksiyonu üstlendiği hatta kalabalık aileler, sık1 akrabalık ve komşuluk ilişkileri ile biçimlenen geleneksel destekler yanı sıra dinsel yardımlara göre daha kurumsallaşmış bir nitelik taşıdığı söylenilebilir (Makal, 1997:214; Güvercin, 2004:91; Makal, 2016:93). Ayrıca sandıktan, ihtiyacı olan esnafa ve diğer esnaf sandıklarına borç verildiği, ustalık belgesi alan ve ilk defa işyeri açanlara sermaye sağlandığı da olurdu (Evren, 1999:12; Akça, 2004:216). Lonca üyesinin sandığı dışında bir yere borçlanması ise ayıp, hatta yasaktı (Büyükboyacı, 1986:168; Şenocak, 2009:423).

Ancak, Osmanlı İmparatorluğuna uzun yıllar hâkim olan bu yapı, sistemin temel kurumlarından biri olarak en gelişkin dönemini yaşadığı 18. Yüzyılın sonlarından itibaren çeşitli faktörlerin etkisiyle daralma ve çözülme süreci içine girmiştir. Ne var ki ilk dönem sanayileşmiş ülkelerde görülen; küçük sanatkârların fabrika üretimine, lonca düzeninin ise ilk olarak işçi hareketlerine daha sonra da meslek sendikacılığına evrilen gelişmesi, Osmanlı'da aynı yörüngeyi takip edemeyince, küçük sanatkârların ülkemizdeki işçi ve sendikacılık hareketindeki rolü sınırlı kalmıştır (Ekin, 1987:36).

\subsection{Tanzimat ve Meşrutiyet Dönemi}

Tanzimat'tan (1839) itibaren devlet, ekonomik ve siyasal tüm kurumlarında köklü değişimlere yönelmiştir. Birçok alanda gücünü kanıtlamış, ekonomik, sosyal ve siyasal atılımları başarmış olan Avrupa, bu dönemden itibaren Osmanlı yöneticilerinin dikkatini çekmiş ve devleti yönetenler bu döneme değin "etkin ve ileri” sayılan Osmanlı yapısını dönüştürerek yeni bir toplum oluşturma düşüncesi içine girmiştir (Talas, 1992:39; Kepenek, 2016:9). Her ne kadar bu süreçte modernleşmenin önüne açan temel aktör devlet olmuş ve bu anlamda gelişmeler "tepeden devrim" biçiminde nitelenmişse de modernleşmenin bu dönemle birlikte başladığını söylemek mümkündür (Özkazanç, 2014:71). Modernleşmenin beraberinde getirdiği ve Batılılaşma olarak adlandırılan tüm sosyo-kültürel değişimler gibi sosyal politika alanındaki değişimler de Tanzimat döneminden günümüze değin hemen her zaman Batı ülkelerinin deneyiminden farklı ve kendine özgü bir biçimde gerçekleşecek, hukuki durum çoğunlukla fiili durum öncesinde gerçekleşecektir. 
Tanzimat ve Meşrutiyet döneminin bizim açımızdan en önemli özelliği ise, bu dönemde iş ilişkileri ve yaşamının örf ve adet hukuku (teamül hukuku) çerçevesinden uzaklaşarak, yazılı hukuk düzenine (pozitif hukuk) geçilmesidir (Uçkan, 1999:160). Ayrıca, "Fabrika-i Hümayunlar" olarak adlandırılan ve ordunun ihtiyaçlarını karşılamak yanı sıra devletin iktisadi yaşamdaki yerini sağlamlaştırma ve sanayileşmeyi gerçekleştirme amacı taşıyan çok sayıda devlet fabrikasının kurulması da bu döneme rastlar. Özellikle çeşitli dokuma, deri-kundura fabrikaları ile birlikte işçi sayısında göreli biçimde artış olmuş (Makal, 2016:83) ve işçilerin çalışma yaşamı ve iş ilişkilerinde korunması ihtiyacı duyulmaya başlanmıştır. Böylece sanayileşen Avrupa ülkelerinde, sanayileşmenin ve kentleşmenin beraberinde getirdiği sefalete karşı işçilerin durumunu iyileştirmek, işçilerle sermaye kesimi arasındaki çatışmaları ortadan kaldırmak, en azından azaltmak hedefiyle (Talas, 1992:13) ortaya çıkan modern anlamdaki sosyal politika uygulamalarının benzerleri de ilk olarak bu dönemde görülecektir. Ancak Osmanlı'nın kendine özgü yapısı nedeniyle sosyal politika uygulamalarının da Batı örneklerinden kısmen farklı geliştiği belirtilmelidir. Diğer yandan ekonomik gelişimi sağlama konusundaki tüm çabalara karşın (Kepenek, 2016:13) çeşitli nedenlerle sanayileşme yönünden bir dönüşüm sağlanamadığ1 (Kepenek,2016:9) hatta kurulu bulunan tezgâh ve atölye sanayinin de yine aynı nedenlerle büyük bir çöküntü geçirerek yıkıma uğradığı, dolayısıyla Batı'da sanayiin nitelikli işgücünü oluşturan bu kesimin Osmanlı'da hızla yok olduğu görülür (Koray, 2008:165; Kepenek, 2016:17).

Sanayileşme çabalarının başarısız olmasının bir nedeni; değişik etnik gruplardan oluşan toplumsal yapının ekonomik işbölümüne dayanması ve dönüşümü sağlayacak yeni bir örgütlenme sürecinin ortaya çıkmamasıdır. Tarımsal artığın, süreklilik kazanan savaşların finansmanında kullanılması zarureti dolayısıyla üretime aktarılamaması da sanayileşme çabalarını olumsuz etkilemektedir. Diğer yandan Osmanlı Duyun-u Umumi yüzünden kamu maliyesini, Balta Limanı Anlaşması (1838) ve Kapitülasyonlar dolayısıyla dış ticaretini, Osmanlı Bankası'nın rolü neticesinde para sunumunu kontrol edememektedir. Azınlıklar ve yabancilara tanınan ayrıcalıklar dolayısıyla oluşan adaletsiz vergi düzeni ve sonuçta ekonomiyi tümüyle düzenleyecek maliye politikası araçlarının bulunmayışı da Osmanlı yöneticilerinin elini kolunu bağlamaktadır (Kepenek, 2016:9-11).

Yine de işçi olarak çalışanların sayılarında yaşanan göreli artış neticesinde, bu işletmelerde çalışanlara yönelik ilk hukuk kuralları da ortaya çıkmaya başlamıştır. Bunların ilki, dönemin koşulları açısından ileri bir sosyal politika düzenlemesi olarak kabul edilen 1865 tarihli Ereğli Kömür Maden-i Hümayun İdaresi Nizamnâmesidir (Karakök, 2011:355; Bedir vd., 2012a:47; Bedir vd., 2012b:65).

Dilaver Paşa Nizamnamesi olarak bilinen bu Nizamname, asıl olarak bölgedeki kömür madenlerinde üretimin düzenli bir biçimde yürümesini amaçlayan hükümler içermekteydi. Bu doğrultuda doğal olarak madenlerdeki çalışanlarda kimi düzenlemelere konu olmuştur. Ancak, işçiler lehine kabul edilebilecek kimi düzenlemeler yapan bu Nizamname, Padişah tarafindan onaylanmadığ 1 için yürürlüğe girmemiş ve gerçek anlamda bir uygulanma şansı bulamamıştır. Ancak bölgedeki kömür madenlerinin yönetim sorumluluğunu da üstlenmiş olan dönemin Ereğli Sancağı Kaymakamı Dilaver Paşa tarafından hazırlanmış bir tasarı olarak, bölgede kısmen de olsa fiili uygulama olanağı bulduğu söylenebilir (Dilik, 1985:93).

İlk sosyal politika uygulamalarının Zonguldak ve Ereğli Kömür Havzası ile ilgili olması şüphesiz bir tesadüf değildir. Bu bölge işçilerin en yoğun olduğu bölgedir. Buna karşın Batı Avrupa ülkelerinin deneyimlerinden farklı bir biçimde, "sürekli" bir işçilik olgusundan söz edilemez. Üretim, genel olarak yıl boyunca köyleriyle madenler arasında gidip gelen işçiler ile sürdürülmeye çalışılmıştır. Niteliksiz, tarım ile ilişkileri devam eden, yıl içinde sadece belirli dönemlerde işçilik yapan, bu anlamda "işçi" den ziyade "köylü-işçi" olarak tanımlanabilecek 
(Makal, 1999:41) işçilerden oluşan yapı içinde sürekli bir işçilik ortaya çıkamamış, isçi sınıfı bilinci ve mücadelesi de oluşmamıştır (Makal, 2006b:123).

Dilaver Paşa Nizamnamesi daha sonra çıkarılan Maadin Nizamnamesi (1869) ile büyük ölçüde geliştirilmiştir. Bu Nizamname ile zorunlu çalışma yasaklanmakta, iş kazalarına karş1 önlemler alınması öngörülmekte, iş kazaları durumunda ise işverenin işçiye tazminat ödenmesine ilişkin hükümler bulunaktaydı (Dilik, 1985:93; Topçuoğlu, 1956:292). Ayrıca Maadin Nizamnamesi Zonguldak ve Ereğli bölgesiyle sinırlı değildir ve İmparatorluğun değişik bölgelerindeki madenlerde uygulanmıştır (Makal, 1997:284; Makal, 2016:102).

Dezavantajlı kesimlere yönelik sosyal yardım amaçlı ilk gönüllü derneklerde, içerde ve dışarda son derece büyük çalkantıların yaşanıldığı bu dönemde kurulmuştur. Örneğin, 1868 yılında Osmanlı Mecruhunî Askeri Muavenet Cemiyeti adı ile Kızılay kurulmuş, özellikle savaş dönemlerinde gerek cephede gerekse de cephe gerisinde sağlık, tedavi ve yardım vb. hizmetleri vermeye başlamıştır (Altan, 2008:68). Yardım baloları, sergiler ve konferanslar düzenleyerek toplumsal dayanışma ve yardımlaşmada etkili olan dernek (Tepekaya ve Kaplan, 2003:148), yoksullara yönelik faaliyetler de gerçekleştirmiştir (Buğra, 2008:136).

Sokaklarda yaşayanlar için Darülaceze, şehit çocukları için darüleytamlar ve babası olmayan, maddi olanakları yetersiz çocukların eğitimi amacıyla çaba gösteren Darüşşafaka da bu dönemde önemli hizmetlerde bulunmuş̧ur (Zengin vd. , 2012:136). Yine bu dönemde II. Abdülhamit tarafından ilk kez sağır, dilsiz ve kör çocuklar için okul kurulduğu (Demirci Akyol, 2014:39) ve engellilerin eğitiminin kamusal politikalara konu olduğu görülür. Ancak bu dönemin sosyal politika uygulamaları olarak sıralanan yukarıdaki örneklerin, "Avrupa'da görülen yararlı uygulamaları geleneksel yollarla ülkeye taşımak" gibi politik önceliklerle sıkı bir ilişki içinde olduğu (Demirci Akyol, 2014:36) gönüllülük ve hayırseverliğe yaslanan bir biçimde şekillendiği ifade edilmelidir. Kaynak kullanımında önceliğin hangi kıstaslara göre saptandığ 1 ise belirsizdir. Bu kurumların tamamında elit bürokrasi söz sahibidir ve Kızılay, Darülaceze gibi örneklerden görülebileceği gibi kamu kaynakları ile bağışlar iç içe geçmiştir (Metin, 2011:186). Örneğin Darülaceze'nin kuruluşu için gereken 72.000 altın liranın karşılanması amacıyla II. Abdülhamid 7.000 altın lira değerindeki eşyasını hediye etmiş ayrıca kendi hazinesinden 10.000 altın lira vermiştir. Kalan miktar için ise piyango düzenlemiş ve bağışlarla birlikte 50.000 altın lira toplanmıştır (Demirci Akyol, 2014:40). Devlet kaynakları ile bireysel bağışlardan sağlanan kaynakların bu iç içe geçmişliği, sağlanan yardımların kapsamını, yeterliliğini ve ulaşılabilirliğini kısıtlar. Devamlılık açısından riskli, ulaşılabilirliği açısından yetersizdir. Elbette bu kurumların gönüllülük esasına dayanması toplumsal hayattaki rollerini azaltmaz ve bu rollerin küçümsendiği anlamına da gelmez (Metin, 2011:186).

Hızlanan yasalaşma gayretlerinin en dikkate değer sonuçlarından bir tanesi durumundaki Mecelle de bu dönemde hazırlanmış ve 1926 yılına kadar, Osmanlı İmparatorluğu'nda bireysel iş ilişkilerinin hukuksal çerçevesini belirlemiştir. Mecelle Avrupa'da olduğu gibi işçi-işveren ilişkilerini her türlü müdahaleden uzak, bireysel sözleşme serbestisi sistemi içinde düzenlemiş ve bu anlamda ferdiyetçi, liberal bir yasal düzenleme olarak nitelenmiştir (Uçkan, 1999:163; Dilik, 1985:93).

Osmanlının son döneminde sivil memur ve askeri personelin dul ve yetimlerini de kapsayacak bir biçimde yaşlılık, malullük ve ölüm sigortaları gibi sosyal güvenlik uygulamaları da başlatılmıştır (Talas, 1992:40-41). Bu amaçla 1866'da kurulan Askeri Tekaüt Sandığı, 1881'de askerler dışındaki devlet memurları için kurulan tekaüt sandığ 1 ve 1890 'da kurulan Seyri Sefain Tekaüt Sandığı bunların ilk örnekleridir (Makal, 1997:215; Makal, 2016:93). Ancak Batıdaki anlamda bir sanayileşme sürecine girilmediği ve bu anlamda "sosyal koruma" talebini ortaya koyacak bilinçte bir işçi kitlesi oluşmadığı, aile yapısı da sosyal koruma birimi olarak fonksiyonunu sürdürdüğü için yukarıda sıralanan sınırlı ve dağınık uygulamalar 1940'lı yılların ortalarına kadar gerçek bir sosyal güvenlik sistemine dönüşememiştir (Güvercin, 2004;91). 
II. Meşrutiyet sonrası oluşan ve göreli daha özgür koşullarda ise sayılarının yüz bini bulduğu tahmin edilen ancak oldukça olumsuz çalışma ve yaşam koşulları içinde bulunan işçilerin grevlerinde bir patlama görülür. Bu grevler formel sendikal örgüt yapısı dışında ve büyük ölçüde ekonomik nitelikli işçi hareketleri biçiminde ortaya çıkmıştır (Makal, 1997:260 262; Makal, 2016:97). İşçiler anayasa artık yürürlükte olduğu için greve gitmiştir ve anayasanın kendi durumlarını düzeltme olanağı sağlayacağına inanmaktadır (Dumont ve Georgeon, 1997:24). Farklı sektörlerde ama özellikle demiryolu alanında baş gösteren bu grevler sonrasında ise (Ökçün, 1996:xi) Hükümet 1909 yılında çıkartılan Tatil-i Eşgal Kanunu ile çalışma yaşamına yönelik doğrudan ilk düzenlemesini gerçekleştirmiştir. Ancak, doğrudan olması dolayısıyla konumuz açısından önemli bu ilk yasal düzenleme ile yasaklamadan yana tavır alınmış, kamuya yönelik hizmet veren kuruluşlarda örgütlenme yanı sıra uygulama alanını ciddi bir biçimde sinırlanarak grevler fiilen yasaklamıştır (Dumont ve Georgeon, 1997:26; Makal, 1997:274; Makal, 2016:99). Böylece devlet, o zamana kadar karışmadığı sendikal gelişmeyi bir anlamda baltalamıştır (Koray, 2000:100). Bu düzenleme ilk iş kanunumuz olan 1936 tarih ve 3008 sayılı İş Kanunu'na kadar, sendika yasağ ${ }_{1}$ açısından ise 1938 tarihli Cemiyetler Kanunu'na kadar yürürlükte kalacaktır (Makal, 2016:100).

\section{CUMHURIYET DÖNEMİ VE SOSYAL POLITÍKALAR}

\subsubsection{0-1935 Dönemi}

Cumhuriyetin ilk yıllarında sanayileşme gayretleri farklı nedenlerle başarısızlığa uğramıştır. Türkiye'nin sanayileşme açısından zaruri olan sermaye ve vasıflı işgücünden yoksun olması, altyapının yetersizliği, 1925'te Aşar vergisinin kaldırılmasının bütçe üzerindeki olumsuz etkileri, yerli sanayiyi koruyacak gümrük tedbirlerinin Lozan Antlaşması'nın dikte ettiği şartlar neticesinde alınamayışı bu nedenlerin başlıcalarıdır. Ancak var olan zorlukları yenmek ve ekonomik kalkınmayı sağlamak Cumhuriyetin en temel hedeflerinden birisi olmuştur. Cumhuriyet bile henüz ilan edilmemişken, İzmir' de İktisat Kongresi'nin toplanması (17 Şubat-4 Mart 1923) bu düşünceyi doğrular. Ülkenin sanayileşmesi konusunda izlenecek politikaların belirlenmesi amacıyla düzenlenen ve ilk "sosyal diyalog", uzlaşı arayışı olarak nitelenebilecek Kongre'ye her ilçeden bir tüccar, bir sanatkâr, bir işçi, bir şirket, bir banka, üç çiftçi temsilcisi olmak üzere sekiz kişi katılmıştır. Toplam 1135 delegenin katıldığı Kongre'de delegelerin yaklaşık onda birini işçi temsilcileri oluşturmuştur (Tokol, 2005:22; Görmüş, 2007:120; Bahçe ve Eres, 2014:17; Makal, 2016:115). Her ne kadar delegelerin seçiminde belirli bir ölçüt ya da kural gözetilmemiş ve özellikle işçi grubunu oluşturan temsilcilerin iş̧̧ilikle ilgili olmadıkları saptaması yapılmış olsa da kongrede işçiler taleplerini dile getirebilmiştir (Kepenek,2012:3233). İşçi grubunun Kongrede ortaya koyduğu talepler şöyledir: Amele olarak anılan emek erbabına bundan böyle işçi denilmesi; olumsuz çalışma koşullarının düzeltilmesi; örgütlenme hakkının tanınması; günlük çalışma süresinin 8 saatle sınırlandırılması; ücretlerin en alt düzeyinin ülkenin geçim durumuyla orantılı olarak her 3 ayda bir belediye meclislerince saptanması ve benzeri. Ayrıca minimum çalışma yaşı olarak sanayi kesimi için 12, madencilik kesimi için 18 yaş önerisi; ara dinlenmelerine, izin günlerine ve sosyal güvenliğe ilişkin başkaca işçi talepleri de Kongrede dile getirilmiştir (Ekin, 1987: 40; Atılgan, 2012:330). Fakat diğer gruplar kendilerine maddi bir yük getirmeyen işçi taleplerinin kabulü, diğer taleplerinin ise reddi doğrultusunda oy kullanmışlardır. Dolayısıyla kendi dönemine göre oldukça ileri kabul edilebilecek işçi taleplerinin bu Kongrede pek dikkate alınmadığı söylenilebilir.

Kongrede temel olarak, ülkenin geneline yayılmış durumdaki yabancı sermaye yerine ulusal sanayinin kurulması ve gelişmesi üzerinde durulmuş ve sonrasında bu amaçla Teşvik-i Sanayi Kanunu (1927) ile Gümrük Tarife Kanunu (1929) çıkarılmıştır. Ne var ki, ne sözü edilen yasal düzenlemeler ne de diğer kredi ve finansman önlemleri, özel sermayeyi harekete 
geçirmeye yetmemiştir. Özel girişime dayalı sanayileşme, 1930'lu y1llara gelindiğinde yerini devletçiliğe dayalı karma ekonomik modele bırakmak durumunda kalmıştır (Koray, 2008:167).

Cumhuriyetin ilk yılları çalışma yaşamı bakımından değerlendirildiğinde ise, tarımda küçük arazi sahipliğinin, sanayide el sanatları ile küçük imalathanelerin hâkim olduğu bir yapının doğal sonucu olarak işgücü içerisinde bağımsız çalışanlar ile ücretsiz aile işçilerinin ağırlıkta olduğu, ücretlilerin ise azınlıkta kaldığı görülür (Makal, 2006a:379).

Türkiye' de çalışanlarla ilgili koruyucu mevzuatın gelişmesi de sosyal, insancıl ve ekonomik düşüncelerle bu dönem ile birlikte başlar. Devlet, ülke ve toplum çıkarları açısından gerekli ve yararlı olduğu inancı ile ekonomik yönden güçsüz ve bağımlı kesimlerin istismarını önlemek amacıyla çalışma yaşamına müdahale etmeye başlamıştır. Cumhuriyet Dönemi'nde devletin çalışma yaşamına ilk müdahaleleri, özetlenen şartlar altında ilk olarak 1921 yılında kabul edilen Zonguldak ve Ereğli Havzai Fahmiyesinde Mevcut Kömür Tozlarının Amale Umumiyesine Olarak Füruhtuna Dair Kanun ile olmuştur (Altan, 2008:70). Bu Kanunla kömür üretiminden arta kalan kömür tozlarının işçilerin genel yararına ayrılması ve açık arttırma ile satılarak parasının Ziraat Bankasına yatırılması öngörülmüştür (Gülmez, 1983:546-547; Tokol, 2005:19). Aynı y1l yürürlüğe konulan Ereğli Havza-i Fahmiyesi Maden Amelesinin Hukukuna Müteallik Kanunla ise, kömür madenlerinde yeraltı işlerinde 18 yaşından küçük çocukların çalıştırılmayacağı kabul edilmiştir. Ayrıca, maden işçilerinin zorla çalıştırılması ve angarya suretiyle bir işe yollanması yasaklanmıştır. Kanun ile işverenlerin iş kazalarına karşı gerekli önlemleri alması zorunlu tutulmuş, çalışma süreleri 8 saate indirilmiş, işveren, devlet ve amele birliği tarafından bir asgari ücret belirlenmesi ve kaza geçiren işçilere parasal yardım yapılması öngörülmüştür (Topçuoğlu, 1956:294; Talas, 1992:84-85; ).

Zonguldak ve Ereğli bölgesindeki kömür madenlerinde çalışan işçilerin hak ve çıkarlarının korunmasına ilişkin 1921 yasasının bir bölümü ise yardımlaşma ve sağlık konularıyla ilgilidir. İşverenler, kurulacak ihtiyat ve yardımlaşma sandıklarına her ay için çalıştırdıkları işçilerin ücretlerinin yüzde birinden az olmamak üzere parasal yardımda bulunmak zorundadır. Böylece, bu sandıklar kendi mensuplarına yaşlılık, hastalık, iş görmezlik durumlarında yardımda bulunabilmiş̧lerdir. Kömür madenlerinde çalışan işçiler açısından bu düzenlemeler, sosyal sigortaların ortaya çıkması doğrultusundaki ilk adımlar olması nedeniyle önemlidir (Talas, 1992:85).

Devletin, Cumhuriyetin ilanından hemen sonra, kömür madenlerindeki çalışma koşulları üzerine eğilmesi ve işgücünü koruyucu önlemler almaya bu kesimden başlamış olması, kuşkusuz bir rastlantı değildir. Gerçekten Türkiye'deki iş̧̧ilerin en yoğun olduğu yer bu dönemde Zonguldak ve Ereğli kömür havzasıydı. Çalışma koşulları tümü ile geri ve Osmanlı İmparatorluğu'ndan kalma bir iki nizamname ile belirlenmiş yetersiz bir koruma rejimi altındaydı. Ayrıca, başka enerji kaynaklarına sahip bulunmayan ülkemizde kömür üretiminin çoğaltılması sanayiin gelişmesi ve askeri açılardan ayrı bir önem taşıyordu (Altan, 2008:70-71). Diğer yandan devletin tıpkı Avrupa'da olduğu gibi modern anlamda sosyal politika uygulamalarında işçileri odak noktasına alması ve buradan işe başlaması olağan karşılanmalıdır.

1924 Anayasası ile ise bireysel özgürlükler ile doğal hukuk anlayışı çerçevesinde önemli adımların atıldığı görülür. Ancak liberal devlet modelinin tipik bir örneği olarak kabul edilen 1924 Anayasası sosyal devlet ilkelerinin uzağında kalmış, sosyal sorunlar bireylere daha çok hak ve özgürlük verilerek çözülmeye çalışılmıştır. 1926 Borçlar Kanunu’nda da, 1924 Anayasası ile benimsenen bu liberal anlayış1 görmek mümkündür (Bedir vd., 2012a:49; Bedir vd., 2012b:67).

1925 y1lında ise Şeyh Sait İsyanını bastırmak amacıyla hükümete olağanüstü yetkiler veren Takriri Sükûn Kanunu çıkarılmış, ancak yasadan kaynaklanan uygulamalar siyasal yaşamdan, düşünce yaşamına kadar birçok alanı etkilemiştir. Muhalif gazetelerin, siyasi partilerin kapatıldığg bu süreçte İstiklal Mahkemeleri kurulmuş (Makal, 1999:168), sendika ve 
dernek kurabilmek neredeyse olanaksız hale getirilmişti. 1933 yılında yapılan bir yasal düzenlemeyle de grev ve lokavt yasakları cezai hükümlerle kuvvetlendiriliyordu (Gülmez, 1983:553; Ekin, 1987:41).

1930'lu y1llara gelindiğinde, ABD'de başlayan ve bütün dünyayı etkisi altına alan 1929 Ekonomik Bunalımı ve bunun ülkemize etkileri, devletin ekonomik hayata daha etkin müdahalesini gerekli kılmıştır (Koray, 2000:102). Bu değişimde şüphesiz 1929 Ekonomik Bunalımı sonrası değişen ve sosyal devlete doğru evrilen devlet düşüncesinin de payı bulunmaktadır. Bu dönemde devlet, işveren olarak dokuma, çimento, kâğıt, cam, maden, şeker gibi sanayi alanlarında fabrikalar kurarak devletçi bir ekonomi politikası izlemeye başlamış, Sümerbank ve Etibank gibi önemli kurumlar sayesinde kamu kesiminde işçi olarak çalışanlar hızla çoğalmıştır. Diğer yandan bu dönemde sanayi kuruluşlarının ihtiyaç duyduğu nitelikli ve sürekli işgücü temininde yaşanan sıkıntıların, sanayileşme çabaları önünde bir engel oluşturduğu düşünülerek, İktisadi Devlet Teşekküllerinde işçiler ve diğer çalışanlar için göreli yüksek ücretler ile beslenme, barınma gibi imkânlar sağlandığını görüyoruz (Makal, 2006a:380). Özellikle kadın ve çocukların çalışma şartlarına ilişkin düzenlemeleri ile geniş kapsamlı sosyal politika tedbirlerini içeren Umumî Hıfzıssıhha Kanunu da bu koşullar içinde hazırlanarak 1930 y1lında yürürlüğe girmiştir (Bedir vd, 2012a:49; Bedir vd., 2012b:67).

$\mathrm{Bu}$ dönemi genel olarak değerlendirirsek, çalışma yaşamına ilişkin mevzuatın büyük bölümünün dolaylı bir nitelik taşıdığını, bu düzenlemelerin hiç birinin iş ilişkilerini bütünsel olarak ele alma amacını taşımadığını, sadece belirli konulara ilişkin sınırlı bir içerikte olduğunu söyleyebiliriz. Türkiye'deki çalışma yaşamını genel çizgileriyle düzenleyecek bir yasa çıkarılması düşüncesi ise kademeli bir biçimde oluşmuştur (Makal, 1999:353). Nitekim bu amaçlarla, iki kez (1927 ve 1932 yıllarında) iş kanunu tasarısı hazırlanmış ve Meclis gündemine getirilmiştir (Gülmez, 1983: 313 ve 343; Talas, 1992:96-101). Ancak, bu tasarılar, Cumhuriyetin kötü bir ekonomik miras devraldığı, ekonomik anlamda güçlenmek için ulusal sanayisini oluşturmak ve geliştirmek zorunda bulunduğu, bu nedenlerle işçilerin de fedakarlikta bulunmasının gerektiği, ayrıca yalnız işçinin değil, "ürkmemesi" için işverenin de korunmasının uygun olacağı düşünceleri ile kanunlaştırılmamış (Altan, 2008:72) nihayet işyerlerinde artan işçi sayısı nedeniyle daha fazla gecikmenin imkansızlığı göz önünde tutularak 1936 yılında ilk iş kanunumuz yürürlüğe girebilmiştir (Güven, 1975:31).

\subsection{6-1945 Dönemi}

Cumhuriyetten hemen sonra başlayan sanayileşme çabaları ve bu doğrultudaki teşvikler emek talebini büyütürken, devletçi politikaların izlendiği 1930 sonrası dönemde, sanayideki gelişmeye koşut biçimde nitelikli işgücüne olan talebin hızla arttı̆̆ gözlenmiştir. Bu çerçevede işgücünün eğitilmesi yanı sıra nitelikli emek arzının kalıcılığı ve sürekliliğinin sağlanması açısından işgücünün belirli ölçülerde korunması ve geliştirilmesi zorunlu hale gelmişti. Ayrıca Türkiye'nin 1932 yılında Uluslararası Çalışma Örgütü'ne (ILO) üye olması ve iş ilişkilerinin uluslararası standartlara yaklaştırılması gerekliliği de, çalışma yaşamının bireysel ve toplu boyutlarıyla bütüncül bir biçimde düzenlemesi ihtiyacını arttırmıştı (Makal, 2006a:380). Tüm bu ihtiyaçların bir neticesi olarak, ülkemizdeki ilk iş kanunu, Haziran 1936'da kabul edilmiş ve 1 y1l sonra, yürürlüğe girmiştir. Bu düzenleme Türkiye'nin endüstri ilişkileri sistemi ve çalışma yaşamı açısından Osmanlı İmparatorluğu da dâhil olmak üzere en keskin aşama olarak değerlendirilebilir (Ekin, 1987:33).

Ancak, 3008 sayılı İş Kanunu'nun, uygulama alanının oldukça dar tutularak öneminin büyük ölçüde kaybolduğu da belirtilmelidir. Ayrıca, 3008 sayılı İş Kanunu'nun o yılların planlı ve devletçi ekonomi politikası ile tek partili politik sistemin izlerini taşıdığı söylenebilir. Kanun, sendikal hak ve özgürlükler konusunda sessiz kalırken, grevi ise açık bir biçimde yasaklamakta 
ve zorunlu hakem uygulamasını getirerek dönemin özelliklerine uygun otoriter bir çalışma ilişkileri sistemini benimsemektedir. Birçok yazar 1936 tarihli bu Kanun'u devlet paternalizminin önemli bir belirtisi olarak yorumlamaktadır (Koray, 2000:103; Koray, 2008:170; Ekin, 1987:42-43; Talas, 1992:101 vd.). Zira bu dönemdeki hâkim görüşe göre, "çalı̧̧ma şartları her şeyden evvel toplum yararına uygun olarak düzenlenmelidir". Bu anlamda devlet, artan işçi sayısını göz önüne alarak hem iş̧̧i-işveren ilişkilerinin uyumlu bir yapıda düzenlenmesini sağlamalı hem de kalkınmayı olumsuz etkileyebilecek bir sınıfsal çatışmanın oluşumunu engellemek üzere uyuşmazlıkları çözmede müdahil olmalıdır. Ulusal çıkarlar açısından uygun olan budur (Ekin, 1987:42).

Söz konusu döneme siyasi açıdan damgasını vuran ise tek parti yönetimi ve halkçılık ideolojisidir. Toplumsal sınıfların varlığı, sınıflar arasındaki çıkar farkları ve mücadeleyi reddeden halkçılık ideolojisi, toplumun farklı meslek erbaplarının oluşturduğu organik bir bütün olduğunu savunuyordu. Bu çerçevede, Batıda olduğu gibi farklı sınıfların çıkarlarını temsil edecek farklı partilere de gerek yoktu ve Cumhuriyet Halk Partisi bütün toplumu temsil edebilirdi (Makal, 2006a:380).

İkinci Dünya Savaşı yılları ise, Türkiye savaşa girmemiş olmasına rağmen etkilerini ekonominin ve sosyal hayatın her alanında hissettirecektir. Bu dönemde reel ücretler savaş öncesinin \%54'ü düzeyine gerilemiş, gelir dağılımı ciddi ölçüde bozulmuştur (Makal, 2004:3; Makal, 2006b:123; Atılgan, 2012:335). Diğer yandan, 1940 yılında kabul edilen ve 1960 yılına kadar yürürlükte kalacak olan Milli Korunma Kanunu ile İş Kanunu'nun birçok düzenlemesi uygulamadan kaldırılacak ve hükümete çalışma koşullarını düzenleme konusunda olağanüstü yetkiler tanınacaktır.

Milli Korunma Kanunu'na göre çıkarılan kararnamelerle çalışma yaşamında başlıca şu sonuçların ortaya çıktığı görülmektedir. Özellikle Zonguldak Maden Kömürü Havzasıyla, Batı Anadolu Linyit Havzasında ve yine tarımda çalıştırılabilir her vatandaşa uygun bir ücret karşıllı̆ında çalışma zorunluluğu konulmuştur. Bütün sanayi işyerleri Hafta Tatili Kanununun uygulama alanı dışına çıkarılmıştır. 16 yaşından büyük erkek çocukların maden işlerinde çalışmasına müsaade edilmiştir. Kadınlarla 12 yaşından büyük kız ve erkek çocukların dokuma sanayinin gece ve gündüz vardiyalarında çalıştırılmalarına izin verilmiştir. Sonuç olarak, Milli Korunma Kanunu'nun çalışma ilişkileri alanına yönelik düzenlemelerinin işgücü açı̆̆ını gidermeye ve üretimi arttırmaya yönelik olduğu söylenilebilir (Makal, 1999:418; Makal, 2006b:123). Diğer yanıyla Millî Korunma Kanunu ile Bakanlar Kurulu'na ekonominin bütününü düzenleme imkânı tanıyan oldukça geniş yetki ve görevler verilmiş, bu yetkilerin kararnameler ile yaşama geçirilmesi olanağı tanınarak, ekonomik sistemden sosyal yaşama, siyasal kararlardan idari uygulamalara kadar birçok alanı etkileyen uygulamalara izin verilmiştir (Akman ve Solak Akman, 2011:75-76). Bu kanuna dayanılarak azalan kamu gelirleri ve artan askeri harcamalar1 karşılamak için Toprak Mahsulleri Vergisi ile Varlık Vergisi getirilmiştir (Bahçe ve Eres, 2014:30). Tarım ürünlerine ve çiftçinin elindeki hayvanlara düşük bedeller karşılığında devletçe el konulmuş, tarımsal ürünlerin azami satış fiyatları belirlenmiş, tarımsal ürünlere aşar vergisine benzer nitelikte ayni vergiler getirilmiş, Varlık Vergisi etnik bir temelde uygulanmış ve sonuç olarak savaşın faturası halka ödetilmiştir (Akman ve Solak Akman, 2011:76-77; Bakan ve Özdemir, 2012:26; At1lgan, 201:335).

$\mathrm{Bu}$ yılların belki de en önemli projesi, daha sonraki yıllarda ideolojik ve siyasi boyutlarıyla çokça tartışılacak olan Köy Enstitüleridir. Esas itibariyle, köy okulları için öğretmen yetiştirmek amaciyla açılan bu okullar (Babahan, 2009:210) dönemin kırsal Türkiye'sindeki sosyal sorun ve ihtiyaçların karşılanabilmesine ilişkin görüş ve hedefleri içeriğinde barındırmış, kalkınmayı gerçekleştirebilecek önemli bir araç olarak görülmüştür. Kır/kent arasındaki sosyoekonomik eşitsizlikleri gidermek, eğitimi farklı nüfus kesimlerine eşit biçimde ulaştırılmak gibi 
işlevlerde yüklenmesi nedeniyle Köy Enstitüleri, önemli bir sosyal politika uygulaması olarak nitelendirilebilir (Babahan, 2009:194-196-209).

\subsection{6-1959 Dönemi}

2. Dünya Savaşı sonrasında devletçi sanayileşmeden liberal politikalara doğru bir geçiş süreci yaşanmış ve kamunun yanında özel sektörün de hızla geliştiği, bu anlamda "karma ekonomi” olarak adlandırılabilecek bir yapı oluşmuştur (Koray, 2008:143). İzlenilen sosyal politikalarda da bir hareketlilik ve canlanma olmuş, bu alanda önemli sayılabilecek adımlar atılmıştır. Devletin rolünün giderek arttı̆̆ 1 bu dönemde eğitim, sağlık ve çalışma yaşamına ilişkin önemli ilerlemelerin sağlandığ 1 görülür.

$\mathrm{Bu}$ gelişmelerin temelinde kuşkusuz Türk siyasal rejiminin 1946 yılında tek parti sisteminden ayrılarak, çok partili demokratik sisteme geçmesi ve işçi sınıfının oy gücü ile siyasal yaşamda bir ağırlık kazanmasının etkileri bulunur (Talas, 1992:125). Ayrıca bu dönem Türkiye ekonomisi ve çalışma yaşamı üzerindeki uluslararası etkilerin arttı̆̆1 bir dönem olarak değerlendirilebilir. Örneğin 1942 yılında refah devleti uygulamalarının temelini oluşturan önemli belgelerden birisi kabul edilen Beveridge Raporu'nun İngiltere'de yayınlanması sonrasinda konunun Türkiye'deki gazetelerde de tartışıldığ 1 ve sosyal güvenlik konusunun siklıkla ele alındığ1 görülür (Buğra, 2008:160; Bedir vd., 2012b:68). Bu makalelerde, kapitalist ülkelerde alınan sosyal güvenlik önlemleri yoluyla kapitalist ve komünist rejimler arasındaki farkların törpüleneceği görüşü dile getirilmiş (Buğra, 2008:160), Batı ülkelerinde yaygınlaşan sosyal güvenlik akımının da etkisiyle ardı ardına yeni sigorta kolları kurularak sosyal güvenlik sistemi geliştirilmiştir (Makal, 2006a:383-384).

1945 yılında Milli Kalkınma Partisi’nin 1946 yılının hemen başında da Demokrat Parti'nin kuruluşları ile başlayan, aynı yıl seçimlerin yapılması ile sürdürülen, 1950 yılında ise seçimle iktidarın el değiştirmesine neden olan siyasal dönüşüm (Boratav, 2003:93) süreci sendikaların kurulup gelişebilecekleri hukuki bir ortamın oluşturulmasını da gerektirmiştir. 1946 yılında Cemiyetler Kanunu değiştirilerek sınıf esasına dayalı derneklerin kurulmasını yasaklayan hükümler yürürlükten kaldırılmış, böylece sendikalar ardı ardına kurularak hızla çoğalmaya başlamıştır. 1947 yılında ise 5018 sayılı İşçi ve İşveren Sendikaları ve Sendika Birlikleri Hakkında (ki) Kanun kabul edilerek yürürlüğe girmiş ve Türkiye' de sendika kurma hakkı ilk kez özel bir kanunla tanınmıştır. Ancak yasa, sendikalar üzerinde yargı denetimi yanı sıra yoğun idari denetime olanak sağlaması, katı bir siyaset yasağı getirmesi, uluslararası mesleki kuruluşlara üyeliği Bakanlar Kurulu'nun iznine bağlaması açılarından eleştirilmiş, dönemin uluslararası normlarının gerisinde kalmıştır (Makal, 2006a:383). Ayrıca sendikaların toplu pazarlık hakları da grev hakkıyla tamamlanmamış, yani toplu pazarlık hakkı eksik kalmıştır. Otoriter devlet anlayışı yanı sıra yeterli bir sanayileşme düzeyine ulaşılamayan bu dönemde, kapsamı ve etkileri sınırlı bir sendikacılık anlayışının benimsendiği görülür. Buna karşın, kurulan 73 sendikada 52 bin civarında işçi örgütlenebilmiştir (Atılgan, 2012:338).

Yine ABD tarafindan 1947 yllında ilan edilen Truman Doktrini ve Marshall Planı'nın uygulamaya sokulması ile yaşanan sürecin, Türkiye' deki sosyal yaşama büyük etkileri olmuş, ekonomi belirli ölçülerde canlanırken, devlet müdahalesini sınırlayıcı bir düzen kurulmuştur (Ertem, 2009:393; Bedir vd., 2012b:69). Bu dönemde siyasal ve ekonomik yönden, sanayileşmiş Batılı ülkelere yönelen Türkiye, bu ülkelerle birlikte uluslararası kuruluşlarda yer alarak uluslararası bir konum ve saygınlık kazanmayı hedeflemiştir. Diğer yandan sendikaların kurulabilmesinin hukuken meşru hale gelmesiyle, ILO'nun temsil açısından aradığ 1 , hükümetlerin yanı sıra, ancak işçi ve işveren kesimlerinin üst mesleki kuruluşları aracılığıyla temsil edilme koşulu da (üçlü temsil koşulu) yerine gelmiş oluyordu. Böylece Türkiye'nin 1936 y1lında başlayan sembolik üyeliği, tam bir üyeliğe dönüşmüş, bu gelişmeler Örgüt ile ülkemiz 
arasındaki ilişkilerde de bir yakınlaşmayı beraberinde getirmiş ve Örgüt'ün sözleşme ve tavsiye kararları, ülkemiz sosyal politikalarına yön vermeye başlamıştır (Altan vd., 2011:80-81).

1945 yılında kurulan İşçi Sigortaları Kurumu sonrasında, yukarıda da belirtildiği gibi ardı ardına kurulan sigorta kolları ile sosyal güvenlik alanında önemli gelişmeler sağlanmıştır. Ücretlilerin toplam işgücü içindeki payının arttığı, hızlı bir kentleşmenin başladığı bu yeni dönem insanların yaşamında köklü dönüşümlere neden olmuş, kentsel yoksulluk, olumsuz barınma ve sağlık koşulları gibi sorunlarla karşılaşılmıştır. Aile yapısının da değişmesi neticesinde sosyal güvenliğe duyulan ihtiyacin şiddetlendiği bu dönemde sosyal güvenlik alanında gelişmelerin kaydedilmesi doğaldır. Ancak sosyal güvenlik alanındaki bu gelişmelerin önemli olmalarına rağmen birçok açıdan yetersiz oldukları da ifade edilmelidir (Buğra, 2008:161).

Ocak 1950 tarihinde yürürlüğe giren 5434 Say1lı yasa ile kurulan Emekli Sandığı ile sosyal sigortalar alanında önemli bir adım daha atılmıştır. Bu yasa ile daha önceki dönemlerde memurların sosyal güvenliklerini sağlamak üzere çıkarılmış olan yasalar ve bu yasalar uyarınca yapılan uygulamalar bir bütünlüğe kavuşturulmuştur (Makal, 1999:429). Aynı dönemde önce Basın İş Kanunu ardından ise Deniz İş Kanunu çıkarılarak geniş bir kesim daha koruyucu mevzuat kapsamına alınmıştır.

1950'li yıllarda hızlanan ve alanları genişleyen sanayileşme, yeni istihdam alanları oluşturmuştur. Sanayi kesiminde çalışan iş̧̧iler daha önceki dönemlere oranla önemli ölçüde çoğalmıştır. Hemen hemen aynı yıllarda, hızlı nüfus çoğalışına koşut kırsal alanda yeni iş olanaklarının yaratılamayışı, kamu hizmetlerindeki yetersizlikler ve toprak düzenine ilişkin sıkıntılar ve benzeri nedenlerle, kırsal kesimlerden büyük kentlere doğru kitlesel göç dönemi de başlar. Bu sosyal ve ekonomik gelişmeler, aileleri tüm üyeleri ile çalışmak zorunda bırakmış ve işçi statüsü altında çalışanların salt sayılarında değil, demografik niteliklerinde de önemli değişiklikler oluşturmuştur (Altan, 2008:74-75).

$\mathrm{Bu}$ dönemde sağlanan olumlu gelişmeler ise şüphesiz ekonomik, sosyal ve siyasal alandaki gelişmeler ile ilintilidir. Siyasi açıdan, çok partili demokrasinin kendine özgü dinamikleri, sağlanan haklar ve gelişmeler üzerinde pekiştirici bir etki yapmıştır. Ekonomik açıdan bakıldığında ise sağlanan ekonomik büyümenin, bireysel hakların daha geniş tutulabilmesine imkân verdiği söylenilebilir. Bu dönemde ulusal gelirde artışlar sağlanmış, ücretlilerin toplam istihdam içindeki payı yükselmiş, İş Kanunu kapsamına girenlerin sayısı artmıştır. Ücretli işgücünün niteliğinde de aşamalı bir dönüşüm yaşanmış, "köylü-işçi" tipi yerini sürekliliğe dayanan yeni ve modern bir işçi tipine bırakmıştır (Makal, 2006a:384-385).

\subsection{0-1979 Dönemi}

27 Mayıs 1960 ihtilalinden sonra bir yandan yeniden devletin önemli bir yatırımc1 olduğu, özel sektörün ise çeşitli araçlarla teşvik edildiği ve desteklendiği planlı bir kalkınma dönemine girilmiştir (Koray, 2008:143). 1963 yılından itibaren yapılan beş yıllık kalkınma planları ile ekonomik ve sosyal kalkınma plana bağlanmış, "sosyal devletin" görev ve sorumlulukları daha şeffaf ve görülebilir hale getirilmiştir (Ekin, 1987:35). Diğer yandan bu dönemde "ithal ikameci" politikaların uygulanması sonucunda, özellikle tüketim mallarının üretimine yönelik bir sanayi ortaya çıkmıştır (Koray, 2008:144).

1960 ihtilalinin en önemli yasal düzenlemesi olarak kabul edilen 1961 Anayasası ise sosyal politika açısından bir dönüm noktası olmuş, o döneme kadar sosyal güvenlik, çalışma koşullarının iyileştirilmesi, parasız ilköğretim gibi konularla sınırlı kalan sosyal politika uygulamalarında önemli genişleme sağlanmıştır (Bedir vd., 2012a:51; Bedir vd., 2012b:70). 1961 Anayasası'nda Türkiye Cumhuriyeti'nin nitelikleri arasında "sosyal hukuk devleti" 
ilkesine ilk kez yer verilmiş, "Sosyal ve İktisadi Haklar ve Ödevler" yine ilk kez Anayasa hükümleri ile düzenlenmişti. Sosyal devlet ve sosyal adalet düşüncelerin bir sonucu olarak ise endüstri ilişkileri sisteminin bütün eksiklik ve yetersizliklerine karşın çağdaş bir yapıya kavuşturulmasına böylece sendika-devlet ilişkilerinin dengeli bir temele oturtulmasına çalışılmıştır (Koray, 2008:173). Bu nedenle gerek 1961 Anayasası, gerekse bu Anayasa hükümleri çerçevesinde kurulmaya çalışılan sosyal ve hukuki düzenin yapılandırılmasında, ILO’nun ilke ve kararlarından geniş biçimde yararlanılmıştır (Altan vd., 2011:84).

Sendikal hakların fiilen temini doğrultusunda ise yeni yasal düzenlemelere gidilmiş, Bülent Ecevit'in Çalışma Bakanı olduğu 1963 yılında 274 sayılı Sendikalar Kanunu ile 275 sayılı Toplu İş Sözleşmesi Grev Lokavt Kanunu kabul edilerek yürürlüğe konulmuştur. Bu düzenlemeler özellikle de grev hakkının nihayet kabul edilmesi nedeniyle işçi hareketinde önemli bir dönüm noktasını olarak kabul edilebilir (Yazıcı, ?:124; Yazıc1, 1996: 138).

1960'lı y1llar öncesinde toplu pazarlık ve toplu sözleşme uygulaması ülkemizde hemen hemen hiçbir uygulama alanı bulamamıştır. Grev hakkının olmaması nedeniyle sendikaların yeterli pazarlık gücüne ulaşamamış olması kuşkusuz bu durumun başlıca nedenidir. 274 ve 275 sayılı kanunların kabulü bu anlamda toplu iş ilişkilerinde yeni ve hareketli bir dönemin başlamasına yol açmıştır. 1961 itibariyle 511 sendikada örgütlü 298 bin işçi varken 1966'ya gelindiğinde sendika sayısı 704'e üye işçilerin sayısı 374 bine ulaşmıştır (Taş, 2012:40-41). İşçilerin hızla örgütlenmeleri ve yeni yasal haklarından yararlanmak amacıyla yaptıkları etkinlikler, endüstri ilişkilerinin diğer tarafını oluşturan işverenleri de yeni sisteme uymaya zorlamış ve endüstri ilişkileri, bir ölçüde de olsa, işçi örgütleriyle işveren örgütleri arasındaki ilişkiler biçimine dönüşmeye başlamıştır. Böylece, 1961 Anayasa'sı sosyal politikada yeni bir dönemin olduğu kadar işçi ve işveren ilişkilerinin de yeni bir dinamizme kavuşmasının başlangicı olmuştur (Koray, 2000:105).

Bir başka yönden bu dönemde 3008 sayılı İş Kanunu'nun toplumsal ve ekonomik yapıdaki gelişmeleri karşılayabilmede yetersiz kaldığ 1 görülmeye başlanmıştı. Zaten daha önce de ifade ettiğimiz gibi kapsam sinırlılıkları nedeniyle ülke genelinde uygulanamıordu. Ayrıca zaman içinde oluşan yeni gereksinimleri karşılamak ve değişen koşullara uyabilmek üzere çeşitli tarihlerde yapılan farklı düzenlemeler, birbiriyle çelişen uygulamalara ve mevzuatta dağınıklığa yol açıyordu. Dahası 1961 Anayasası ile olan uyumsuzlukları da yeni bir iş kanununun çıkarılmasını zorunlu hale getirmekteydi. Bu nedenlerle 1964 yılında yeni bir iş kanunu tasarısı hazırlanmış, bu tasarı 1967 yılında 931 sayı ile kabul edilerek yürürlüğe girebilmiştir. 931 sayılı İş Kanunu ile engellilerin ve eski hükümlülerin istihdamı gibi birçok yeni düzenlemeye yer verilmiştir (Altan vd., 2011:84).

Ancak 931 sayılı İş Kanunu, yaklaşık 3 yıl uygulandıktan sonra, özelikle meclis komisyonlarının seçiminde Anayasaya aykırılık bulunduğu gerekçesiyle Anayasa Mahkemesi tarafından şekil yönünden iptal edilmiştir. Bu nedenle 931 sayılı İş Kanunu'nun neredeyse aynısı olan bir yasal düzenleme hatta birkaç nokta dışında madde sayıları dahi değiştirilmeden 1971 yılında kabul edilmiş ve 1475 sayılı İş Kanunu olarak yürürlüğe girmiştir (Tunçomağ, 1971:37). 1475 sayılı İş Kanunu o tarihten 2003 yılında 4857 sayılı İş Kanunu'nu kabul edilene dek, üzerinde çeşitli zamanlarda, çeşitli kanunlarla değişiklik yapılmasına karşın bireysel iş ilişkilerini düzenleyen temel metin olma niteliğini korumuştur.

1964 y1lında ise 506 sayılı Sosyal Sigortalar Kanunu kabul edilerek konuya ilişkin dağınık yasalar derlenmiş ve bir araya getirilmiştir. Uygulama alanı İş Kanunu'nun uygulama alanından farklı tanımlanmış, bu suretle dar bir kapsamdan uzaklaşmanın en önemli adımı atılmıştır. İşçi sigortaları yerine sosyal sigortalar anlayışına geçilmiş, sosyal güvenliğe yönelik bir düşünce genişliğine ulaşılmıştır. Sosyal sigortalardan yararlanmak için aranılan koşullar ise hafifletilmiş ve sağlanan parasal ödemelerle sağlık yardımları genişletilmiştir. Böylece, 
uluslararası ölçülere yaklaşılmış, hatta bazı alanlarda bu ölçülerin ilerisine geçilmiştir (Talas, 1992:195).

1971 yılında ise, 1497 sayılı Esnaf ve Sanatkârlar ve Diğer Bağımsız Çalışanlar Sosyal Sigorta Kurumu Kanunu ile bir başka kesimin Sosyal Sigortalar kapsamına katıldığı görülür. 70'li yılların sosyal politika tarihi açısından önemli bir diğer gelişmesi de sosyal diyaloğa yönelik ilk gerçekçi adım olan "Toplumsal Anlaşma" nın imzalanmasıdır. 1978 yılında Türk-Işs ile Ecevit Hükümeti arasında imzalanan bu Anlaşma demokrasi ve ekonomiyi güçlendirmek, kalkınmayı sağlıklı ve dengeli bir biçimde hızlandırmak, refahı toplumun tüm kesimlerine yaygınlaştırmak, kamuda çalışma barışını sağlamak gibi amaçlarla hazırlanmıştır (Görmüş, 2007:122).

Bu yıllarda sosyal politika açısından belki de en önemli düzenleme ise 1976 y1lında yürürlüğe giren, 2022 sayılı "65 Yaşını Doldurmuş, Muhtaç, Güçsüz ve Kimsesiz Türk Vatandaşlarına Aylık Bağlanması Hakkında Kanun" dur. Zira bu düzenleme ülkemizde doğrudan kamu tarafindan finanse edilen, kapsamı belirgin ve bu anlamda çağdaş nitelikli ilk sosyal yardım düzenlemesi olarak kabul edilebilir (Metin, 2011:186). 2005 y1lında "engelli aylığı, bakıma muhtaç engelli aylığ 1 ve engelli yakını aylığını" da kapsamına alan bu düzenleme, özellikle "kanunen bakmakla mükellef kimsesi bulunmayan" ifadesi nedeniyle eleştirilmiştir. Zira bu ifade nedeniyle bir kişiye aylık bağlanabilmesi için, eşinin, annesinin, babasının, kardeşlerinin ve çocuklarının bulunmaması diğer bir ifadeyle gerçek anlamda "kimsesiz" bulunması gerekmektedir. Ya da bakmakla mükellef olan bu kişilerin bireye bakamayacak derecede zorluk içinde bulundukları mahkemece tespit edilmelidir. Tüm bu nedenlerle hak temelli bir düzenleme olmasına karşın sorumluluğu devletten önce aileye yüklemesi nedeniyle modern sosyal politika esasına tam oturmayan bir yapıda olduğu belirtilmelidir (Metin, 2011:187-188). 2013 yılında ise "kimsesiz olma" kriteri kalkmış ve gelire ilişkin objektif bir ölçüt belirlenmekle birlikte muhtaçlık durumuna karar verme yetkisi Sosyal Yardımlaşma ve Dayanışma Vakıflarına bırakılmıştır.

1970'li y1llarda bütün dünyayı etkileyen petrol krizi, ithal ikamesine dayanan mevcut sanayileşme politikasının kendi iç sorunlarıyla birleşmiş ve koalisyon hükümetleri önlem alabilmede aciz kalmıştır. Cari işlemler dengesindeki açık, bütçe açıklarıyla birleşmiş, bir yandan dış borçlar artarken diğer yandan da enflasyon yükselmeye başlamıştır. Bu yıllarda ekonomik büyüme önce duraksamış ve ardından da gerilemiştir. Ekonomideki sorunun sosyal harcamalardan kaynaklandığı düşüncesi ise sosyal devleti erozyona uğratmıştır. Tasarruf zorunluluğu kamu kesiminde yatırımların durmasına yol açmış, özel sektör açısından belirsiz ekonomik durum ve faiz oranlarının yükselişi yeni istihdam alanlarının açılmasını engelleyerek, nüfus artış hızının da devamı neticesinde işsizlik oranlarında önemli yükselişlere neden olmuştur. 1970'lerin sonuna gelindiğinde ise Türkiye, hem ekonomik hem de siyasi süreçlerin bütününü neredeyse felç eden bir kriz ortamına girmiştir. Ülkemizde görülen bu kargaşa ve bunalım sendikaları da etkilemiştir. Sendikaların faaliyetleri bu dönemde tartışma konusu olmuş, sendikalar yaşanılan sıkıntıların kaynaklarından biri olarak gösterilmiştir.

Sorunların çözümü için hazırlanan ve tipik bir IMF uyum programı olarak nitelenebilecek 24 Ocak Kararlarının uygulanması ise, mevcut siyasi ortam içinde pek mümkün görünmüyordu. Bu nedenle 12 Eylül 1980 askeri darbesinin en önemli taahhütlerinden birisi, bu programın uygulanması ve Türkiye'de dışa açık bir sanayileşme modelinin yürürlüğe girmesi olmuştur (Buğra, 2008:197).

\subsection{0-2001 Dönemi}

12 Eylül 1980'de Silahlı Kuvvetler devlet yönetime el koymuş, siyasal partilerle birlikte yaşanılan sıkıntıların temel nedenlerinden biri olarak görülen sendikaların da faaliyetleri 
durdurulmuş; Türk-İs DİSK, MİSK, Hak-İş gibi konfederasyonlar ve bunlara bağlı sendikalar kapatılmıștır. Yine yapılan bir yasal düzenleme ile serbest toplu pazarlık sürecinin yerini zorunlu hakem uygulaması almış ve süresi biten toplu sözleşmeleri yenileme görevi Yüksek Hakem Kurulu'na verilmiştir (Altan vd., 2005:48; Atılgan, 2012:353-354).

1982 Anayasası ile ise 1961 Anayasasına kıyasla daha kısıtlı bir anayasal çerçeve için de de olsa demokrasiye dönülmüştür. Ancak askeri vesayetin fiilen devam ettiği bu yeni dönemde kamusal politikalar belirlenirken toplumun geniş kesimleri ile "sınırlı da olsa bir uzlaşı" arayışına gereksinim duyulmamıştır. 1983 yılında 2821 sayılı Sendikalar Kanunu, 2822 sayılı Toplu İş Sözleşmesi, Grev ve Lokavt Kanunu, toplu iş ilişkileri ve yaşamına yeni bir biçim verme çabalarının ürünü olarak ortaya çıkmış, çalışanların mücadeleleri ekonomik alana hapsedilerek daraltılmıştır. Ayrıca sendika hakkı sınırlanmış, grev yasakları genişletilmiş, birçok durumda zorunlu hakem uygulaması öngörülerek serbest toplu pazarlık alanı daraltılmış ve sendikalar üzerinde ağır bir denetim sistemi oluşturulmuştur (Koray, 1994:198-199 dan aktaran Altan vd., 2005:48).

Uluslararası Çalışma Örgütü'nün daha önceki dönemlerde onaylanmış birçok Sözleşme ilke ve kuralından gerek yasal düzenlemelerle gerekse de fiili uygulamalarla uzaklaşılan bu dönemde, Türkiye sürekli olarak ILO denetim organlarının gündemine gelmiş ve bu dönem Türkiye ile Örgüt arasındaki ilişkilerin giderek gerildiği bir dönem olmuştur (Altan vd., 2011:85).

24 Ocak Kararları ile uygulamaya başlanılan, 12 Eylül sonrasında da sürdürülen yapısal uyum ve istikrar tedbirleri, sosyal politika alanındaki dönüşüme dair net ifadeler içermese de ekonomi politikalarında temel bir paradigma değişikliğine işaret etmektedir (Durmaz, 2016:154; Özgüden, 2012:394) ve bu tedbirler ile birlikte serbest rekabete dayalı piyasa ekonomisi ilkeleri egemen olmuştur. İthalatta koruma oranları düşürülerek yerli üretim dış rekabete açılmış, yabancı sermayenin ülkeye girişi kolaylaştırılmış, kamu kesiminin ekonomideki yerinin küçültülmesi amaçlanmıştır. 1970'lerin ithal ikameci sanayileşme ve birikim modeli terk edilerek dışa açık büyüme ve neo-liberal uygulamaların işlerlik kazandığ hâkim söylemine göre, maliyetlerinin özellikle de ücretlerin olabildiğince düşük tutulması gerekmektedir (Altan, 2008:77; Bedir vd., 2012a:52; Bedir vd., 2012b:71-72). Zira geçmiş dönemlerin göreli dişa kapalı ekonomik sisteminde ücretler bir maliyet unsuru olmanın yanı sıra bir talep unsuru olarak da işlev görmüş ve yüksek ücretler dolayısıyla oluşan maliyetler ürün ve hizmetlerin satış fiyatlarına yansıtılabilmiştir. Oysa dışa açık büyüme politikalarının izlendiği bu yeni dönemde uluslararası rekabet dolayısıyla maliyetlerin düşürülmesi gerekliliğine ilişkin söylem, ücretler üzerinde büyük bir baskı oluşturmuş, gelir dağılımı emek aleyhine bozulmuştur.

Enflasyon oranlarının oldukça yüksek seyrettiği bu dönemde, sosyal güvenlik fonları hızla erirken, toplu pazarlık sisteminin askıya alınmasının da etkisiyle reel ücretler önemli ölçüde azalmış, gelir dağılımındaki eşitsizlikler daha da büyümüştür. Diğer yanıyla sanayi alanında kamu yatırımlarının azaldığı ve kamu kuruluşlarının özelleştirildiği bir döneme girilmiştir. Devletin yatırımcı olmaktan elini çektiği bu dönemin, devlet anlayışı ve yapılanması açısından da ciddi bir değişim anlamına geldiği açıktır. Daha açık bir ifadeyle, devlet "sosyal" olmaktan hızla uzaklaşmış, bütçe açıkları, borsa ve faizdeki iniş çıkışlar gibi küresel ekonominin ve neo-liberal politikaların dayattı̆̆ konular gündemi işgal etmiş, adalet, güvenlik ve dış politika konuları ile sınırlı bir devlet anlayışı gelişmiş̧tir. Serbest piyasa ve rekabet gücü en gözde kavramlar haline gelirken, işsizlik, yoksulluk gibi konular ise sorunlar artmasına karşın toplum gündeminin kıyısında kalmaktan öteye gidememiş, bu sorunların çözümünde toplumun değil bireyin sorumlu olduğu anlayışı yaygınlaşarak, devletin sorumluluğunu sivil topluma terk etmesini gerekli gören neo-liberal ideoloji güçlenmiştir (Koray, 2008:145 ve 177).

Ancak kapitalizmin geliştiği bu ortamda aile ve akrabalık ilişkileri gibi geleneksel yapıların ihtiyaçları gidermede yetersiz kalması sonrasında artan sosyal huzursuzluklar, sosyal 
politikaların üretilmesi ve uygulanmasını zorunlu kılmıştır. Bu düşüncelerle 1983 yılında Sosyal Hizmetler ve Çocuk Esirgeme Kurumu (SHÇEK) kurulmuş, dağınık biçimdeki kamu sosyal hizmet uygulamalarının tek çatı altında toplanmasına çalışılarak muhtaç çocuk, yaşlı ve engellilere yönelik hizmet verilmeye başlanmıştır.

1986 yılında ise yaygın ismiyle "Fak Fuk Fon" olarak bilinen Sosyal Yardımlaşma ve Dayanışmayı Teşvik Fonu (SYDTF) kurulmuş, fonda toplanan paraların il ve ilçelerde yoksul ve ihtiyaç sahibi kişilere dağıtımını ise tüm il ve ilçelerde kurulacak olan Sosyal Yardımlaşma ve Dayanışma Vakıfları (SYDV) üstlenmiştir. Geniş kapsamlı ilk sosyal yardım programı olan Fonun amacı kuruluş kanununda, fakru zaruret içinde ve muhtaç durumda bulunan kişilere yardım etmek, sosyal adaleti pekiştirici tedbirler alarak gelir dağılımını adil bir hale getirmek, sosyal yardımlaşma ve dayanışmayı teşvik etmek şeklinde özetlenmiştir.

Uygulama, "sosyal devlet" anlayışı ile ve "hak temelli" bir yaklaşımı içermediği, eş deyişle hayırseverlik yaklaşımının bir uzantısı olduğu eleştirisiyle karşılaşsa da (Buğra, 2008:199; Durmaz, 2016:162), yoksullukla mücadelede devletin doğrudan bir biçimde ve aktif şekilde rol almaya başlaması açısından önemlidir (Demirhan ve Kartal, 2014:261). Ancak bu yapının geçmişe kıyasla daha iyi bulunması "hayırseverliğin kurumsallaşması" olarak tanımlamasını da engellemez. Zira SYDV'nin mevcut işleyişi, geçmişteki vakıf anlayışından çok da farklı değildir. Belki de tek fark, geçmiş dönemlerde devlet, gönüllü kuruluşlara kaynak aktararak ve manevi desteğini hissettirerek sosyal yardım alanında faaliyet gösterirken SYDV ile bizzat kendisi vakıf kurmuş, gönüllü bağış bekler duruma gelmiştir (Metin, 2011:191).

Yeşil Kart uygulaması da artan sosyal huzursuzlukları bastırmak üzere 1992 yılında uygulamaya geçirilmiştir. Genel sağlık sigortasına geçişte bir ilk adım olarak görülen bu uygulama, yeterliliği ve yapısı tartışılabilir olsa da düşünce olarak hak temelli ve bu anlamda çağdaş olarak nitelendirilebilir. Yeşil Kart uygulamasından, hiçbir sosyal güvenlik kurumunun güvencesi altında olmayan yoksullar yararlanmış, tetkik ve ilaç giderleri ile ayakta veya yataklı tedavileri Sağlık Bakanlığı'na bağlı hastanelerde ve sevk edilmeleri durumunda üniversite hastanelerinde ücretsiz olarak yapılmıştır. Bu uygulama 2012 itibariyle yerini Genel Sağlık Sigortası'na bırakmıştır.

Genel bir değerlendirme yaparak, yaşlılara, yoksullara, engellilere, dul ve yetimlere yönelik hak temelli sosyal politika uygulamalarında bu dönemde bir gelişme görüldüğü söylenmelidir (Altan, 2008, 76-77). Elbette bu yıllarda yapılan ve yukarıda kısaca ele aldı̆̆ımız söz konusu yasal düzenlemelerin yeterliliği ya da yetersizliği tartışılabilir ve elbette bu yasal düzenlemeler, hukuki bir zemin veya meşruiyet kurma açısından önemlidir. Ancak Türkiye için daha önemli olan, mevcut yasal düzenlemelerin (yoksulluğun ortadan kaldırılması, sosyal adaletin sağlanması, engellilerin toplumsal yaşama katılımının temini, çocukların korunması vb. konularda) ne ölçüde uygulamada var olabildiği/uygulanabildiği meselesidir (Koray, 2008:164). Diğer yandan bu düzenlemelerin temelinde "sosyal devlet" düşüncesinin var olduğunu söyleyebilmek güçtür. Zira önce bireyin ve akrabalık ilişkilerinin, sonrasında dini ve hayırsever düşüncelerle hareket eden gönüllü kuruluşlar gibi devlet dışı mekanizmaların birincil rol üstlendiği bu uygulamalar; genellikle düzensiz, kayıt dışı ve siyasal etkiye açık bulunmakta ve 19. Yüzy1la bir geri dönüş olarak değerlendirilmektedir (Dişbudak ve Bozkulak, 2010:105-106; Çelik, 2010:69). 1980'li yıllarda başlayan ve "muhafazakâr hayırseverlik" modeli olarak nitelenen bu sosyal politika anlayışı, Refah Partisi'nin 1994 yerel seçimlerinde elde ettiği başarı sonrasında yükselişe geçmiş ve 2000'li yıllarda merkezi hükümet politikası olarak yaygınlaşmıştır (Çelik, 2010:69).

Aynı dönemde sendikacılık hareketi üzerinde ise özellikle reel ücretlerdeki düşüşün etkilerinin hissedildiği görülür (Makal, 2006a:388). Bu süreçte işçiler meydanlara çıkmış, 1987 yılından itibaren başlayan grevlere 1989 yılında zirveye ulaşan grev-dışı eylemler eklenmiştir (Altan vd., 2005:49). Yoğun grev dalgası 1990'lı yılların başında da devam etmiş, 1989-1993 
yılları arasında yapılan toplu pazarlıklarda işçiler sendikaları aracılığıyla önemli kazanımlar elde etmiştir. Ancak çalışma yaşamında gerilimlerin arttığı bu yıllarda, verimlilik artışının ücretlerin gerisinde kaldığını iddia eden işverenler, sendikalı işçileri işten çıkararak, kısmi zamanlı çalışmayı teşvik ederek, işin bir kısmını alt işverene yükleyerek sendikaların baskısından kurtulabilmenin çarelerini aramaya girişmiştir. $\mathrm{Bu}$ yıllar, işverenlerin Türkiye'deki iş mevzuatının çağın zorunlu kıldığı esnekliğe yeterince cevap veremediğini öne sürdüğü, yasal değişikliklerin yapılmasının gerekliliğini ifade etmeye başladığı yıllardır. İşverenlerin bu taleplerine 2003 yılında yürürlüğe giren 4857 sayılı İş Kanunu'nda cevap verilmiş, esnek çalışma biçimlerinden bazıları yasal olarak düzenlenmiştir (Altan vd., 2005:50).

Özellikle 1998 sonrası yaygınlaşan özelleştirmeler, işverenlerin kayıt dışı, taşeron işçi kullanımına yönelmeleri bir yanıyla işsizliği 2000-2002 yılları arasında neredeyse iki kat arttırırken (Altan vd., 2005:50) aynı süreçte sendikalaşma oranlarının önemli ölçülerde düşmesine yol açmıştır (Atılgan, 2012:359).

\subsection{2 ve Sonrası Dönem}

2001 ekonomik krizi, ekonomik ve sosyal alanda büyük sıkıntılar oluşturmuştu. Faizler aniden ve rekor düzeyde firlamış, uzunca bir dönemdir izlenen sık1 para politikasından vazgeçilerek, "dalgalı kur" politikasına geçilmişti. Binlerce işyeri kapanmış, yüzbinlerce kişi işsiz kalmıştı. Krizden çıkış için başlatılan "güçlü ekonomiye geçiş programı" yoksulluğu daha da arttırmış ve derinleştirmişti. Tüm ülkede toplu eylemler gerçekleştirilirken, Türkiye'nin bir sosyal patlamanın eşiğinde olup olmadığı tartışılmaya başlanmıştı. İşte bu atmosferde krizin yoksul aileler üzerindeki ekonomik etkisini azaltmak ve yoksullukla mücadele eden kamu kurumların kurumsal kapasitelerini güçlendirmek üzere Dünya Bankası'ndan 500 milyon dolar tutarında kredi alınmış ve devletin de mali katkılarıyla 2002 yılında Sosyal Riski Azaltma Projesi (SRAP) başlatılmıştır (Zabc1, 2003:216; Bedir vd., 2012a:112). SYDTF'nin uygulamacı kuruluş olduğu proje, "Hızlı Yardım, Şartlı Nakit Transferi, Kurumsal Geliştirme ve Yerel Girişimler" olmak üzere, birbirini tamamlayan dört bileşenden oluşmaktadır. Hızlı Yardım bileşeni ile SYDV'nın yoksul ailelere yönelik yardım programlarını desteklemek amaçlanmış ve 100 milyon dolar ayrılmıştır. İkinci bileşen olan Şartlı Nakit Transferleri için ise 480 milyon dolar kaynak ayrılmıştır (Zabcı, 2003:233). Bu çerçevede çocuk ölümlerini ve hastalanma oranlarını azaltmak, temel sağlık ve beslenme hizmetlerinden yeterli düzeyde yararlanamayan 0 6 yaş grubunda yer alan çocukları güvence kapsamına almak amacıyla, sağlık muayenelerini yaptırmaları şartıyla ailelere düzenli nakdi para transferi yapılmaktadır. Yine maddi olanaklarının yetersizliği yüzünden çocuklarını okula gönderemeyen ailelere, ilk ve ortaöğretime giden çocuklarını okula düzenli olarak devam ettirmeleri şartıyla her ay nakdi olarak yardım yapılmaktadır (Bakan ve Özdemir, 2012:35).

SRAP kuşkusuz bir sosyal yardım projesidir ve özellikle yukarıda ele alınan ilk iki aşaması yoksullukla doğrudan mücadele amacındadır (Zabc1, 2003:237). Ancak bu Proje bazı açılardan haklı bir biçimde eleştirilmiştir. İlk olarak projenin söylenmese de asıl amacının sosyal patlamanın eşiğine gelmiş büyük halk kitlelerini teskin etmek ve uysallaştırmak olduğu, bu anlamda yoksulların durumunu iyileştirmekten çok, yoksulların "iyi durumda olanlar" için bir tehlike oluşturmasını engelleme amacında olduğu ifade edilmektedir. Zaten Projenin mimarı durumundaki Dünya Bankası'nın "yoksulluğu gidermek, ortadan kaldırmak" gibi bir hedefinin bulunması da beklenemez. Projenin içeriğinde yoksulluğu "azaltma" ya da "hafifletme" sözcüklerinin kullanılması da bu düşünceyi doğrular (Zabc1, 2003:216). Ayrıca yoksullukla mücadele sosyal devletin bir görevi iken sorunun çözümünün bir projeye havale edilmesi tartışmalıdır. 
SYDV uygulaması ise daha önceki dönemlerde kurulmuş olmasına karşın son dönemlerde önemli bir araç durumuna gelmiş, gerek yardımlardan yararlanan kişi sayısında gerekse de yapılan yardımların miktarında büyük bir artış gerçekleşmiştir. 2004 yılında Sosyal Yardımlaşma ve Dayanışma Genel Müdürlüğü kurulmuş, 1986 yılından itibaren faaliyet gösteren ve yoksullukla mücadelenin başlıca aracı durumundaki SYDTF merkezi ve kurumsal bir yapıya kavuşturulmuştur. 2011 yılından itibaren ise yeni kurulan Aile ve Sosyal Politikalar Bakanlığına bağlı Sosyal Yardımlar Genel Müdürlüğü olarak faaliyetlerini sürdüren Genel Müdürlük, eğitim için materyal yardımı, ücretsiz kitap yardımı, öğle yemeği yardımı, engelli öğrencilerin okullarına ücretsiz taşınması gibi faaliyetlerde bulunmaktadır (Bakan ve Özdemir, 2012:35-36).

Ancak uygulamanın, özellikle seçim dönemlerinde yapılan yardımların miktarında önemli düzeyde bir artış yaşanması ve yardımların seçimleri kazanmanın kritik olduğu yer ve bölgelerde yoğunlaşması nedeniyle artan bir biçimde eleştirildiği görülür. Diğer yandan kaynakların ülkenin gereksinimlerine aykırı, rasyonel olmayan bir biçimde kullanıldığı, "hak arama" yerine "itaat etme" kültürünün beslendiği de ifade edilmektedir (Demirhan ve Kartal, 2014:263; Çelik, 2010:65). Ayrıca SYDV uygulaması ile yoksulluğun giderilmesinden, ortadan kaldırılmasından ziyade yoksulluğun yönetilmesine çalışıldığı söylenilebilir. Yoksulluk belli bir düzeyde tutularak, söz konusu durum siyasi devamlılığın bir aracına dönüştürülmüştür. Yapılan yardımların yoksulluğu giderici etkisinin sınırlı olması hatta yok denecek kadar az olması bu düşünceyi doğrular (Metin, 2010:198). Bütün bunlar nedeniyle de SYDV uygulamasının Klientalist ve Paternalist özellikler taşıdığı belirtilmektedir. Bu eleştirilere göre; Klientalisttir, çünkü sunulan hizmetler karşılığında siyasal bir destek talebinde bulunmaktadır. Paternalist özellikler taşımaktadır, çünkü kolektif hakları sınırlamakta, örgütlülüğü dizginlemekte ve itaati ön plana almaktadır (Çelik, 2010:69-70; Metin, 2011:182-183; Durmaz, 2016:160-163).

Diğer yandan bu dönemde sosyal politika açısından oldukça önemli gelişmelerde kaydedilmiştir. Öncelikle 2004 yılında Anayasada yapılan değişiklik ile yine bu dönemde onaylanan BM Engellilerin Haklarına İlişkin Sözleşme gibi, "usulüne göre yürürlüğe konulmuş milletlerarası andlaşmaların" kanun hükmünde olduğu ve bunlar hakkında Anayasaya aykırılık iddiası ile Anayasa Mahkemesine başvurulamayacağının düzenlenmiş olması sosyal politika açısından önemlidir. Böylece temel insan hakları belgelerinin aynen ulusal yasal düzenlemeler gibi işlem görmesi sağlanmıştır.

Yine bu dönemde sosyal politika açısından bir gelişme de engelliler alanında görülür. 2005 yılında engellilerin toplumsal yaşama tam ve etkin katılımının sağlanması amacıyla kısaca "Engelliler Kanunu" olarak bilinen yasal düzenleme yapılmıştır. Esasen 1990'lı yılların ikinci yarısından itibaren engellilere yönelik uygulamalar için politika belirleme ve kurumsal yapı oluşturma faaliyetleri yoğunlaşmıştı. Bu çerçevede 1997 yılında Özürlüler İdaresi Başkanlığı kurulmuş, 1999 yılında ilk Özürlüler Şûrası toplanmıştı. Ancak bir yandan yeni düzenlemeler yapan, diğer yandan engellileri ilgilendiren bazı yasal düzenlemelerde değişiklikler getiren Engelliler Kanunu, engelli bireylerin haklarını koruma altına alan özel bir yasal düzenleme olarak büyük bir önem taşımaktadır. İnsan haklarına dayalı ve ayrımcılıkla mücadele eksenli bir sosyal politikanın çerçevesini belirleyen düzenlemenin ruhunu, engellilik alanında firsat eşitliği, insan hakları ve ayrımcılığın önlenmesi ilkeleri oluşturmaktadır. Bu esaslar doğrultusunda ulaşılabilirlik, istihdam, bakım ve sosyal güvenliğe ilişkin sorunların çözümü, engelli bireylerin her bakımdan gelişmeleri ve toplumsal yaşama tam katılımlarının sağlanması için gerekli düzenlemelerin yasal çerçevesi belirlenmiştir. Böylelikle engellerin kaldırılması yönünde önemli sayılabilecek adımlar atılmıştır (Şişman, 2011:177 ve 216; Şişman vd., 2010:18).

2006 yılında çıkarılan 5510 sayılı Sosyal Sigortalar ve Genel Sağlık Sigortası Kanunu ile 18 yaşından küçüklerin anne babalarının sigortalı olup olmamalarına bakılmaksızın yani 
herhangi bir ön şart aranmadan Genel Sağlık Sigortalısı kapsamına alınması ise yine konumuz açısından çok önemlidir.

12 Eylül 2010 Referandumu ile yapılan Anayasa değişikliği de Anayasa Mahkemesi'ne bireysel başvuru yolunu açması, memurlara sendikal haklar tanıması seyahat hakkını anayasal güvenceye alması vb. nedenlerle konumuz açısından dikkate değer gelişmelere örnek gösterilebilir.

2004 yılından itibaren Milli Eğitim Bakanlığı'nın ücretsiz kitap dağıtması ve 2012 yılından itibaren zorunlu eğitimin süresinin 12 yıla çıkarılması, yükseköğrenimde öğrenci harçlarının kaldırılması, engelli ve yaşlı bireylere bakım parası ödenmesinin yolu açılması gibi uygulamalar yine sosyal politika açısından bu dönemin kayda değer gelişmeleridir.

$\mathrm{Bu}$ dönemde konumuz açısından belki de en önemli gelişme ise, 2011 yılında Aile ve Sosyal Politikalar Bakanlığının kurulmasıdır. Uygulamada bakanlığın kadın ve aile kavramlarına yaslandığı görülse de, 1980'li yılların hemen başında "sosyal politika" derslerinin sakıncalı bulunarak yükseköğrenim programlarından çıkarıldığı, bu disipline bölüm ve anabilim dallarının adlarında dahi yer verilmediği hatırlanacak olursa, sosyal politikaya bir bakanlığın adında yer verilesi daha büyük bir anlam kazanacaktır.

$\mathrm{Bu}$ dönemin genel bir değerlendirmesi yapılacak olursa; sosyal politikaların finansmanı açısından nesnel koşulların oluştuğunu, ancak modern anlamda hak temelli, kurumsal, düzenli ve standart uygulamaların ve böylece gerçek anlamıyla "sosyal devletin" oluşturulması doğrultusunda bir siyasi iradenin gerçekleşmediğini söyleyebiliriz. Diğer yandan temelinde hangi sebep ya da saik bulunursa bulunsun, önemli ve övgüye değer birçok gelişmenin var olduğunu da belirtmeliyiz.

\section{SONUC}

Türkiye'de modern anlamda ilk sosyal politika uygulamaları Batılılaşma çabalarının ortaya çıktığı Tanzimat ve Meşrutiyet döneminde görülür. Ancak yaşadığımız coğrafyanın kendine özgü yapısı yanı sıra ilk sanayileşme hareketlerinin ve dolayısıyla işçi-işveren ilişkilerinin geç bir dönemde ortaya çıkması sosyal politika açısından farklılıkları da beraberinde getirmiştir. Örneğin ilk dönem sanayileşmiş ülkelerde küçük sanatkârlar lonca ekonomisinin ortadan kalkmasıyla birlikte fabrikaların nitelikli işgücünü oluştururken ve lonca düzeni meslek sendikacılığına evrilirken, Osmanlı' da lonca düzeni dağılırken sanayileşmenin yaşanmaması bu nitelikli işgücünün yok olması sonucunu doğurmuştur.

$\mathrm{Bu}$ dönem işçilerin en yoğun olduğu bölge Zonguldak ve Ereğli kömür havzasıdır. Gerek Osmanlı'da gerekse Cumhuriyet dönemindeki ilk sosyal politika uygulamaları da bu bölgeye yöneliktir. Ancak bu bölgede dâhi süreklilik özelliği taşıyan bir işçilik olgusundan, işçi sinıfı bilinci ve mücadelesinin oluştuğundan söz edilemez. Biraz da bu nedenle Türkiye'de "zorla çalıştırma" gibi insanlık dışı bir uygulama 2. Dünya Savaşı’nın sonuna kadar devam edebilmiştir. Devlet ise çalışma yaşamına yönelik dolaysız ilk müdahaleyi gerçekleştirdiği yasal metin olan 1909 tarihli Tatil-i Eşgal ve 1925 tarihli Takriri Sükûn Kanunu'nda olduğu gibi yasaklayıcı bir yaklaşımı benimseyerek sendikal örgütlenmeye karşı tavır almıştır. Kızılay ve Darülaceze gibi sosyal amaçlı ilk derneklerde büyük çalkantıların yaşanıldığı bu dönemde kurulmuştur. Bu derneklerde devletin ileri gelenleri söz sahibidir, kaynakların hangi kıstaslara göre dağıtıldığı belirsizdir, devlet kaynakları ile bireylerden sağlanan kaynaklar iç içe geçmiştir.

Osmanlı'nın son dönemleri ve Cumhuriyet'in ilk dönemlerinde çalışma yaşamı ile iş ilişkilerine yönelik düzenlemeler ise sadece işçiyi değil ürkütülmemesi için sermaye ve işverenin de korunması, üretimin arttırılması gibi amaçlarla eş deyişle toplumun yararı gözetilerek, bütüncül yaklaşımdan uzak ve dar bir çerçevede oluşturulmuştur. 
1930'lara gelindiğinde devletin ekonomik ve sosyal sisteme daha etkin müdahale etmeye başladığı görülür. Bu değişimde 1929 Ekonomik Bunalımı sonrası değişen ve dünyada sosyal devlete doğru evrilen devlet düşüncesinin de şüphesiz bir payı bulunur. Devletçi sanayileşmenin yaşandığ 1 bu dönemde artan işçi sayısı, uluslararası normlara yaklaşma ihtiyacının hissedilmesi gibi nedenlerle 3008 sayılı İş Kanunu'nun hazırlandığı böylece endüstri ilişkileri sistemimiz ve çalışma yaşamımız açısından en önemli aşamanın geçildiği görülür. Bu döneme siyasi açıdan damgasını vuran ise sınıf kavramını reddederek toplumun farklı meslek gruplarından oluşan organik bir bütün olduğunu savunan halkçılık ideolojisidir.

2. Dünya Savaşı sonrasında devletçi sanayileşmeden liberal politikalara doğru bir dönüşüm başlamış, eğitim, sağlık ve çalışma yaşamına ilişkin önemli ilerlemeler sağlanmıştır. Çok partili demokratik sisteme geçilen bu dönemde ilk kez sendikal haklar tanınmış, İşçi Sigortaları Kurumu kurulmuş ve sonrasında sosyal sigortalar alanında önemli adımlar atılmıştır. Ücretli işgücünün niteliğinde de aşamalı bir dönüşüm yaşanmış, modern bir işçi sınıfı oluşmaya başlamıştır.

1960 Anayasası ise sosyal politika açısından bir dönüm noktası olarak kabul edilebilir. Gerek Anayasa'da "sosyal hukuk devleti" ilkesine yer verilmesi gerekse Anayasaya dayanılarak hazırlanan diğer yasal metinler sosyal politika uygulamalarında önemli bir gelişme sağlamıştır. Grev hakkı ilk kez tanınmış, işçi sigortaları yerine sosyal sigorta anlayışına geçilmiştir.

1980'li yıllar ise sendikal faaliyetlerin durdurulduğu, çalışma yaşamı ve iş ilişkilerine yeni bir biçim verilen yıllar olmuştur. Uluslararası standartlardan hızla uzaklaşılan bu dönemde yoksulluk, işsizlik gibi sorunlar artmış, bu sorunların çözümünde toplumun değil bireyin sorumlu olduğu anlayışı yaygınlaşarak, devletin sorumluluğunu sivil topluma terk etmesini gerekli gören neo-liberal ideoloji güçlenmiştir. SYDV gibi, temelinde "sosyal devlet" düşüncesinden ziyade Osmanlı' dan miras alınan hayırsever düşüncelerin olduğu yapılar ile bir kesime göre "muhafazakâr hayırseverlik" modeli adlandırılabilecek bir yapı benimsenmiş, 2000'li yıllarda ise bu yapı daha yerleşik hale gelmiştir. Bir başka ifadeyle sosyal politikalar ve uygulama istenilen düzeyde kurumsallaşmasa da hayırseverlik kurumsallaşmış, gelenek ile modernliğin farklı sentezleri ile uygulama kendine özgü bir karakter kazanmıştır. Diğer yandan Osmanlıdan bugüne, sosyal politikanın ve "sosyal devlet" anlayışının zaman içinde ortaya çıkan gelişmelere koşut biçimde ve aşamalı bir gelişme gösterdiği, bir yandan kurumsallaşma yolunda yeterli olmasa da bir ilerleme sağlanırken diğer yandan nitelik ve nicelik olarak özellikle son yıllarda sosyal koruma düzeyinin arttı̆̆ söylenilebilir.

Ancak halen Türkiye'de, bireylerin, sosyal sorunlar karşısında hak temelli politikalar ile kurumsal yollardan korunduğu, sosyal adalet ve sosyal refah hedefine yönelen çağdaş bir devlet düşüncesine ulaşılamadığı tespiti yapılabilir. Sosyal politika standartlarımız ise Batı Avrupa standartlarının gerisindedir. Bu durumun temel nedeni, toplumsal sınıfların zayıflı̆̆ 1 dolayısıyla demokrasinin ve sosyal hakları da içerecek bir biçimde insan haklarının gelişememesi ve geniş halk kitlelerinin kurumsal sosyal politika taleplerinin oluşmamasıdır.

\section{KAYNAKÇA}

Akça, G. (2004). Âhilik geleneği ve günümüz Fethiye esnafı, Türkiyat Araştırmaları Dergisi, 14, 209-219.

Akman, Ş. T. ve Solak A. (2011). II. Dünya Savaşı yıllarında Türkiye'de hububat üretiminin vergilendirilmesi. Hacettepe Hukuk Fakültesi Dergisi, 1(2), 73-91.

Altan, Ö. Z. (2008). Sosyal politika. Eskişehir:Açıköğretim Fakültesi Yayınları.

Altan, Ö. Z. vd. (2005). İşçi profil araştırması:Eskişehir örneği. Eskişehir:Anadolu Üniversitesi Yayınları.

Altan, Ö. Z. vd. (2011). Uluslararası çalışma normları. Eskişehir:Açıköğretim Fakültesi Yayınları. 
Atılgan, G. (2012). Türkiye'de toplumsal sinıflar:1923-2010. 1920'den Günümüze Türkiye'de Toplumsal Yap1 ve Değişim (Ed. Alpkaya, F. ve Duru, B.), Ankara:Phonix Yayınevi.

Dumont, P. ve Georgen, F. (1997). Bir imparatorluğun ölümü (1908-1923). (Çev. Tanilli S.), Yenigün Haber Ajans1.

Babahan, A. (2009). Bir sosyal politika projesi olarak köy enstitüleri. Alternatif Politika, 1(2), 194-226.

Bahçe, S. Eres, B. (2012). İktisadi yapılar, Türkiye ve değişim. 1920'den Günümüze Türkiye'de Toplumsal Yapı ve Değişim (Ed. Alpkaya, F. ve Duru, B.), Ankara:Phonix Yayınevi.

Bakan, S. ve Özdemir, H. (2012). Sosyal politika açısından CHP ile AKP'nin karşılaştırılması. Akademik Yaklaşımlar Dergisi, 3(1), 22-50.

Bedir, E. vd. (2012a). Sosyal politika. (Ed. Oral İ. ve Şişman Y.). Eskişehir:Açıköğretim Fakültesi Yayınları.

Bedir, E. vd. (2012b). Sosyal politika I. (Ed. Oral İ. ve Şişman Y.). Eskişehir:Açıköğretim Fakültesi Yayınları.

Boratav, K. (2003). Türkiye iktisat tarihi 1908-2002. İstanbul:İmge Kitabevi.

Buğra, A. (2008). Kapitalizm, yoksulluk ve Türkiye’de sosyal politika. İstanbul:İletişim Yayınları.

Büyükboyacı Y. (1986). Türk esnafının sosyal yapısı ve sosyal değişme temayülleri. Sosyoloji Konferansları, 21, 159170.

Çelik, A. (2010). Muhafazakâr sosyal politika yönelimi:hak yerine yardım-yükümlülük yerine hayırseverlik. İ.Ü. Siyasal Bilgiler Fakültesi Dergisi, 42, 63-81.

Demirci Akyol, E. (2014). Sultan II. Abdülhamid döneminde sosyal politika uygulamaları. Sosyal Politika Çalışmaları, 14(31), 33-47.

Dilik, S. (1985). Atatürk döneminde sosyal politika. Ankara Üniversitesi SBF Dergisi, 40(1), 93-102.

Dilik, S. (1988). Sosyal güvenliğin tarihsel gelişimi. Ankara Üniversitesi SBF Dergisi, 43(1), 41-80.

Durmaz, O. S. (2016). Neo-Liberal Sosyal Politika Rejiminin Tesisi ve AKP. Çalışma ve Toplum Dergisi, 1(2016), 143-167.

Ertem, B. (2009). Türkiye-ABD ilişkilerinde Truman Doktrini ve Marshall Planı. Balıkesir Üniversitesi Sosyal Bilimler Enstitüsü Dergisi, 12(21), 377-397.

Ekin, N. (1987). Türkiye'de endüstri ilişkilerinin gelişimi ve 1936 İş Kanunu. Sosyal Siyaset Konferansları, 35-36, 33-51.

Evren, B. (1999). Osmanlı esnafı. İstanbul:Doğan Kitapçılık.

Görmüş, A. (2007). Türkiye'de sosyal diyaloğun gelişimi. Çalışma ve Toplum Dergisi, 14, 115-140.

Gülmez, M. (1983).Türkiye belgesel çalışma ilişkileri tarihi (1936 öncesi). Ankara:Türkiye ve Orta Doğu Amme İdaresi Enstitüsü Yayın1.

Güven, E. (1975). Sosyal politika (ders notları). Eskişehir: Eskişehir İktisadi ve Ticari İlimler Akademisi.

Güvercin, C. H. (2004). Sosyal güvenlik kavramı ve Türkiye'de sosyal güvenliğin tarihçesi. Ankara Üniversitesi Tıp Fakültesi Mecmuas1, 57(2), 89-95.

İTO (2006). Loncadan oda'ya. İstanbul.

Karakök, T. (2011). Zonguldak kömür havzasında bir yardım sandığı:Amele Birliği. ZKÜ Sosyal Bilimler Dergisi, 7(13), 351-367.

Karasoy, Y. (2004). Âhi kelimesi ve Türk kültüründe âhilik. Türkiyat Araştırmaları Dergisi, 14, 1-23.

Koray, M. (1994). Değişen koşullarda sendikacılık. İstanbul:TÜSES Yayınları.

Koray, M. (2000). Sosyal politika. Bursa:Ezgi Kitabevi.

Koray, M. (2008). Sosyal politika. Ankara:İmge Kitabevi.

Makal, A. (1997). Osmanlı İmparatorluğunda çalışma ilişkileri:1850-1920. Ankara:İmge Kitabevi.

Makal, A. (1999). Türkiye'de tek partili dönemde çalışma ilişkileri:1920-1946. Ankara:İmge Kitabevi.

Makal, A. (2004). 65. yılında milli korunma kanunu, çalışma ilişkileri ve iş mükellefiyeti üzerine bir inceleme, tartışma metinleri serisi. Ankara:Ankara Üniversitesi Siyasal Bilgiler Fakültesi Yayını. 
Makal, A. (2006a). Dünden bugüne Türkiye'nin toplumsal yapısı. İçinde. M. Zencirkıran (ed.), Cumhuriyetten 21. yüzyıla Türkiye'de çalışma ilişkileri (ss.375-398). Ankara:Nova Yayınları.

Makal, A. (2006b). Zonguldak Kent Tarihi Bienali Bildiriler Kitabı. İçinde Zonguldak ve Türkiye toplumsal tarihinin acı bir deneyimi olarak iş mükellefiyeti. İstanbul.

Makal, A. vd. (2016). Çalışma ilişkileri tarihi. (Ed. Makal A.). Eskişehir:Açıköğretim Fakültesi Yayınları.

Metin, O. (2011). Sosyal politika açısından AKP dönemi:sosyal yardım alanında yaşananlar. Çalışma ve Toplum Dergisi, 1(2011), 179-200.

Ökçün, A. G. (1996). Ta’til-i Eşgal Kanunu, 1909 belgeler-yorumlar. Ankara:SPK Yayınları.

Özcan, K. (2006). Anadolu'da Selçuklu kentler sistemi ve mekânsal kademelenme. ODTÜ Mimarlık Fakültesi Dergisi, 23(2), 21-61.

Özdemir, S. (1996). Türkiye'de zorunlu çalışma uygulamaları. Sosyal Siyaset Konferansları, 42, 181-213.

Özgüden M. (2012). Türkiye'de seçkinler. 1920'den Günümüze Türkiye'de Toplumsal Yap1 ve Değiş̧im (Ed. Alpkaya, F. ve Duru, B.), Ankara:Phonix Yayınevi.

Özkazanç, A. (2014). Cumhuriyet döneminde siyasal gelişmeler: tarihsel-sosyolojik bir değerlendirme. 1920'den Günümüze Türkiye'de Toplumsal Yapı ve Değișim (Ed. Alpkaya, F. ve Duru, B.), Ankara:Phonix Yayınevi.

Sevinç, N. (1978). Osmanlılarda sosyo-ekonomik yapı, cilt 1. İstanbul:Kutsun Yayınevi.

Şenocak, H. (2009). Sosyal güvenlik sistemini oluşturan bileşenlerin tarihi süreç 1şığında değerlendirilmesi. Sosyal Siyaset Konferansları Dergisi, 56, 409-468.

Şişman, Y. (2011). Türkiye'de özürlülere yönelik yasal düzenlemeler. Sosyal Siyaset Konferansları Dergisi, 60, 169221.

Şişman Y. vd. (2010). Özürlülerin çalışma yaşamına katılma gereği ve Türkiye'de bu bağlamda uygulanan sosyal politikaların genel bir değerlendirmesi -kota yönteminin uygulanmasına ilişkin bir Eskişehir örneği-, Eskişehir:Anadolu Üniversitesi Yayını.

Talas, C. (1992). Türkiye'nin açıklamalı sosyal politika tarihi. Ankara:Bilgi Yayınevi.

Taş, H. Y. (2012). Toplumsal sınıfların değişim sürecinde, sendikalar ve sendikaların geleceği. Hak-Işs Toplum Bilimleri Dergisi, 2012 (1), 28-48.

Tokol, A. (2005). Türk endüstri ilişkileri sistemi. Ankara:Nobel Yayınları.

Topçuoğlu, H. (1956). Etibank ve sosyal politikası. Ankara Üniversitesi Hukuk Fakültesi Dergisi, 13(1), 287-328.

Tunçomağ, K. (1971). Türk iş hukuku, cilt I, İstanbul: Sulhi Garan Matbaası.

Uçkan, B. (1999). Mecelle'de iş hukuku düzeni. Ankara Üniversitesi Siyasal Bilgiler Fakültesi Dergisi, 54(1), 159173.

Yazıcı, E. (?). Osmanlı'dan günümüze Türk işçi hareketi ve Türk Harb-İş. Ankara:Türk Harb-İş Sendikası Eğitim Yayınlar1.

Yazıcı, E. (1996). Osmanlı'dan günümüze Türk işçi hareketi. Alternatif Yayınları.

Zabcı, F. C. (2003). Sosyal Riski Azaltma Projesi:yoksulluğu azaltmak mı, zengini yoksuldan korumak mı?. Ankara Üniversitesi SBF Dergisi, 58(1), 215-239. 